\title{
Introns increase gene expression in cultured maize cells
}

\author{
Judy Callis, ${ }^{1}$ Michael Fromm, ${ }^{2}$ and Virginia Walbot \\ Department of Biological Sciences, Stanford University, Stanford, California 94305 USA
}

\begin{abstract}
Using electroporation-mediated gene transfer, the gene encoding the Slow $(S)$ migrating polypeptide of the maize (Zea mays L.) alcohol dehydrogenase-1 (Adh1) enzyme has been introduced stably and transiently into maize cells containing an endogenous Fast (F) ADH1 electromorph. In stable transformants an 11.5-kb fragment was sufficient to program normal $S$ expression relative to the endogenous $F$ allele. In transient assays, Adh1-S gene constructs lacking the 9 Adh1-S intervening sequences (introns) were expressed at levels 50- to 100-fold less than the intact gene; the presence of intron 1 alone restored levels of gene expression to those found with the intact gene. The last two introns also stimulate Adh1-S expression, but the level is threefold below that of the intact gene. The expression of a chimeric chloramphenicol acetyltransferase (CAT) gene utilizing the $5^{\prime}$ promoter and 3' polyadenylation regions of the Adh1 gene was increased 100-fold by the addition of sequences containing the Adh1 intron 1. The Adh1 intron 1 sequences did not stimulate CAT expression when located outside the transcribed region. When located within the transcribed region, the Adh1 intron 1 region efficiently stimulated CAT expression only when located between the promoter and the CAT coding region. A construct containing the $A d h 1$ intron 1 fragment produced 40-fold more mRNA than a construct containing an equivalent cDNA fragment. Both the Adh1 intron 1 and the intron from a second maize gene, Bronze1, stimulated expression from other promoters (cauliflower mosaic virus 35S and nopaline synthase) and of other coding regions (luciferase and neomycin phosphotransferase II) as well. These results indicated that introns increase both Adh1 and chimeric gene expression in maize and the optimal location for such an intron is near the 5' end of the mRNA.
\end{abstract}

[Key Words: Maize; alcohol dehydrogenase; splicing; chimeric genes; introns]

Received July 13, 1987; revised version accepted October 19, 1987.

The coding regions of many eukaryotic genes are interrupted by noncoding regions, intervening sequences, which are removed from the nascent mRNA in a multiple-step process collectively called splicing. The ability of extracts to splice in vitro-synthesized RNA, combined with mutational analysis, has greatly advanced our knowledge of the mechanism(s) of splicing and the nucleotide sequence requirements (for recent reviews, see Padgett et al. 1986; Maniatis and Reed 1987; Sharp 1987). In contrast, comparatively little experimental evidence exists defining the role introns play in the expression of genes in vivo. The demonstration of alternate patterns of splicing to create new proteins or regulate the temporal expression of particular proteins (for review, see Leff et al. 1986) suggests a role for intervening sequences in increasing the diversity of gene products produced from a single locus. Introns have been proposed to facilitate the recombination of separate exons (protein domains) and therefore the evolution of new proteins (Darnell 1978; Doolittle 1978; Gilbert 1978). Fi-

Present addresses: ${ }^{1}$ University of Wisconsin, Madison, Wisconsin 53706 USA; ${ }^{2}$ USDA-ARS, Plant Gene Expression Center, Albany, California 94710 USA. nally, introns have been shown to be an important component for normal expression of a few mammalian genes, for example, $\beta$-globin (Hamer and Leder 1979; Buchman 1986), SV40 late mRNAs (Gruss et al. 1979; Hamer and Leder 1979; Hamer et al. 1979; Lai and Khoury 1979|, and mouse dihydrofolate reductase (Gasser et al. 1982). Other genes, however, such as the herpes simplex virus (HSV) thymidine kinase $(t k)$ gene (Buchman 1986) and the polyoma virus middle-T gene (Treisman et al. 1981) are expressed at similar levels regardless of the presence or absence of introns. The mechanism for intron dependence and the generality of the effect of introns on the expression of eukaryotic genes in vivo is not known.

In plant cells, the first examples of chimeric gene expression utilized genes that lacked introns (Bevan et al. 1983b; Fraley et al. 1983; Herrera-Estrella et al. 1983). In the one case where the effect of introns was examined in plant cells, the gene for the seed storage protein phaesolin was expressed at similar levels with or without its introns (Chee et al. 1986). Consequently, it was assumed that introns were not important for plant gene expression.

We show here normal expression of the intact maize alcohol dehydrogenase-1 (Adh1) gene (Freeling and Ben- 
Callis et al.

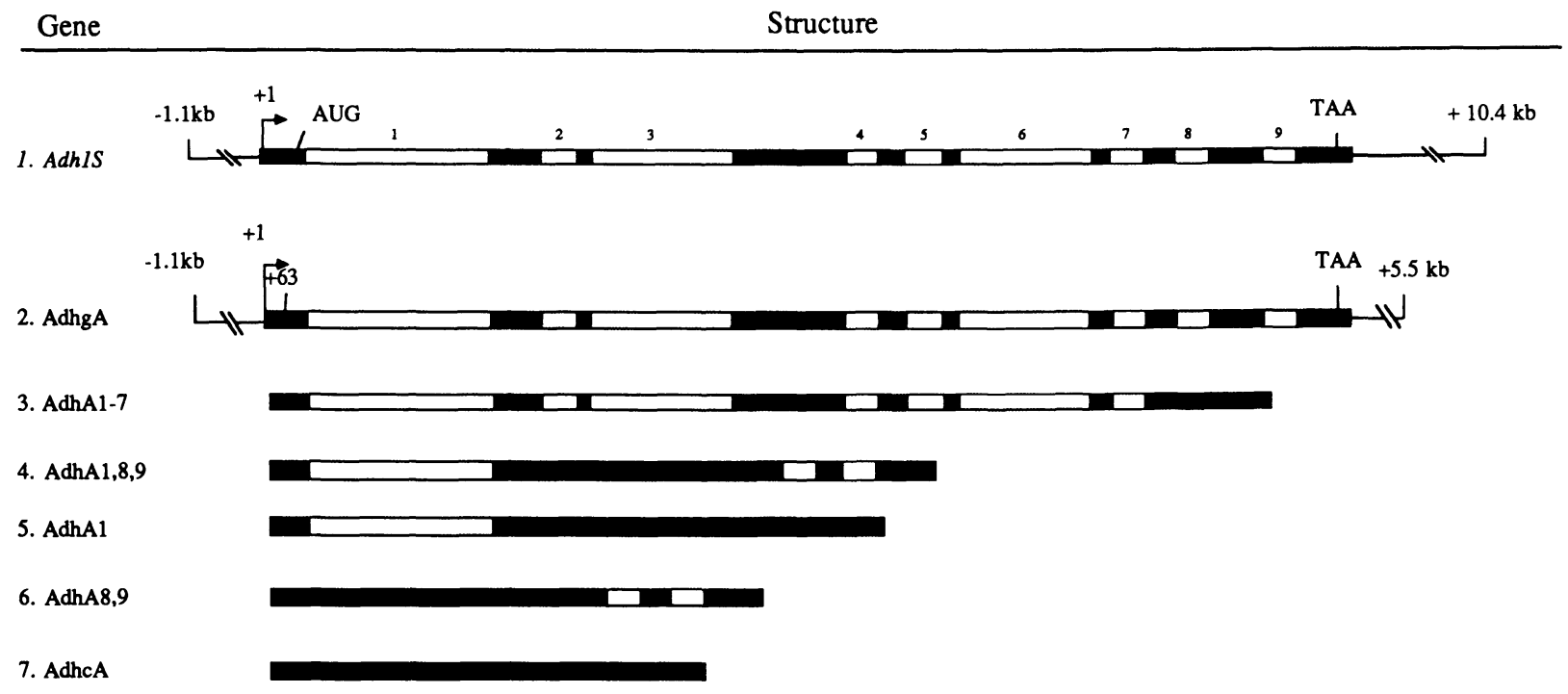

Figure 1. Map of the maize Adh1-S genes stably and transiently introduced into maize protoplasts. Line 1 shows the map of the maize Adh1-S gene stably introduced into maize cultured cells. The 11.5-kb BamHI fragment encoding the maize Adh1-S gene (Bennetzen et al. 1984) shown above was ligated into the $\mathrm{kan}^{\mathrm{r}}$ plasmid, pCaMVNEO. Lines 2-7 are the structures of the maize Adh1-S genes transiently introduced into maize cultured cells. For transient experiments the Adh1-S gene was truncated at the 3' end. The $A d h 1-S$ genes containing deletions of some or all of the intervening sequences are shown below. The flanking regions (identical to line 2) are not redrawn. +63 represents the $5^{\prime}$ junction used in the construction of $A d h 1$-S genes under control of the $35 S$ promoter from CaMV (see Material and methods). The box designates the transcribed region; the filled boxes represent exon sequences; open boxes represent intervening sequences. The upstream and downstream flanking regions are designated by thin lines and their lengths relative to the transcription start site $(+1)$ are marked.

nett 1985) in transiently and stably transformed maize (Zea mays L.) cells after electroporation-mediated gene transfer. However, only very low levels of chloramphenicol acetyltransferase (CAT) activity were found using a chimeric Adh1CAT gene. Because the intact Adh1 gene and the chimeric Adh1CAT gene have identical 5'- and 3 '- flanking regions, we looked for sequences within the transcribed region of $A d h 1$ that might influence CAT expression. We found that expression of the Adh1 coding region and the CAT coding region was dramatically increased by the addition of an intron.

\section{Results}

\section{Stable expression of Adh 1-S in maize cells}

Figure 1, line 1, shows a diagram of the maize Adh1-S gene which was introduced into cultured Black Mexican Sweet (BMS; ATCC 54022) maize (Zea mays L.) cells via electroporation. Cultured cells are an appropriate host for the study of $A d h 1$ expression because the gene is normally expressed in these cells. Thus, all of the transcription factors necessary for the expression of an introduced Adh1 gene are present. Because the electrophoretic mobility of the endogenous ADHl-F activity is distinct from that encoded by the Adh1-S gene, the expression of an introduced Adh1-S gene could be readily distinguished from that of the endogenous gene by activity staining of electrophoretically separated native proteins. The presence of the endogenous ADH1-F activity also provided an internal control to verify that changes in ADHI-S activity were specific to the intro- duced Adh1-S gene. Because it was not possible to select directly for transformed cells with ADH1-S activity, the $11.5-\mathrm{kb}$ DNA fragment containing the Adh1-S gene (Bennetzen et al. 1984) was inserted in both orientations into pCaMVNEO (Fromm et al. 1986), creating pCaMVneoAdh42 and pCaMVneoAdh43. pCaMVNEO contains the $35 \mathrm{~S}$ promoter from cauliflower mosaic virus (CaMV) in front of the neomycin phosphotransferase II (NPT II, $n e o)$ gene. The presence of neo activity in cells confers resistance to the antibiotic kanamycin. Therefore, transformed maize cells containing pCaMVneoAdh 42 and pCaMVneoAdh43 were selected for by their ability to grow on kanamycin-containing media.

To determine whether the kanamycin-resistant calli were expressing the nonselected Adh1-S gene, protein extracts from individual transformants were electrophoresed on native acrylamide gels and the gels stained in situ for ADH activity (Fig. 2). The electrophoretic migration of the ADHl activity encoded by the introduced gene is shown in Figure 2 (lane 1), and is designated S:S to represent the dimer structure of the Slow $(S)$ isozyme. This ADHI-S activity is readily distinguishable from the endogenous ADH1-F activity present in the BMS cell line (Fig. 2, lane 2), and is designated F:F, for the dimer structure of the Fast $(\mathrm{F})$ isozyme.

The two $\mathrm{ADHl}$ protein monomers, $\mathrm{S}$ and $\mathrm{F}$, associate randomly to form active dimers (Freeling 1974). Hence in a cell expressing the two ADHl polypeptides at equal levels, ADHl activity separates into three bands of activity ratios 1:2:1 (SS:SF:FF). Woodman and Freeling (1981) have described $S$ and $F$ alleles from different 


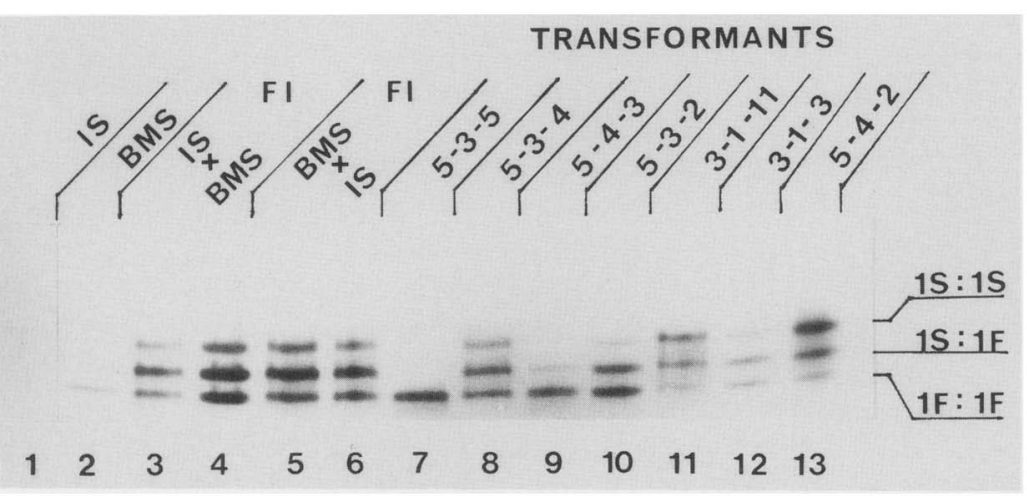

Figure 2. ADH activity gel of stable transformants. Protein extracts were electrophoresed on native gels and stained in situ for ADH activity. (Lane 1) Seed extract from the maize inbred line $1 \mathrm{~s} 2 \mathrm{p}$; represents the electrophoretic mobility of the cloned Adh1-S gene. (Lane 2) Extract from the recipient maize BMS suspension line which produces an $F$ isozyme. (Lanes 3-6) Extracts of calli produced from 1s2p/ BMS heterozygote embryos. (Lanes 7-13) Calli extracts from individual transformants. 1S:1S represents the $\mathrm{ADHl}$ activity from the dimerization of $\mathrm{S}$ polypeptides, $1 \mathrm{~F}$ : 1F designates the dimerization of $\mathrm{F}$ polypeptides and $1 \mathrm{~S}: 1 \mathrm{~F}$ represents the heterodimer of an $\mathrm{F}$ and an $\mathrm{S}$ polypeptide. inbred lines of maize that when present in an $\mathrm{F}_{1}$ heterozygote, produce $S: F$ ratios that differ from $1: 2: 1$, as a result of differences in the rates of synthesis for the two polypeptides. Therefore, to use these S:F ratios to assess the efficiency of expression of the transfected Adh1-S gene, it was important first to determine the ADHl activity ratios in calli when the Adh1-S gene is present in its normal chromosomal environment and at an equivalent copy number to the BMS $1 \mathrm{~F}$ allele. Therefore, F/S heterozygotes were constructed by reciprocally crossing the two maize inbred lines BMS (the inbred line from which the suspension line was derived) and Berkeley Slow (BKS, the inbred line from which the Adh1-S gene was isolated), and callus was derived from immature embryos. The ADH1 activity in extracts from representative calli is shown in Figure 2, lanes 3-6. The isozyme ratios in natural heterozygous calli (equal copy number control) was very close to the expected $1: 2: 1$. Thus, the endogenous $A d h 1-F$ expression served as an internal control for the level of ADH1-S activity expected for two copies of the introduced Adh1-S gene.

The extracts from transformant calli (Fig. 2, lanes $7-13$ ) had a wide range of SS:SF:FF activity ratios, in contrast to the activity ratios of $F_{1} F / S$ heterozygotes (Fig. 2, lanes 3-6). For example, one transformant did not have any S:S activity (lane 7); others had S:S levels greater (lanes 11 and 13) or less (lanes 9 and 10) than the endogenous ADH1-F activity. Lane 8 shows a transformant that contained S:S activity at a level equivalent to the $F: F$ isozyme, a pattern indistinguishable from the $F_{1}$ control lanes.

Table 1 summarizes the results from the transformation experiments. Approximately $70 \%$ of the kanamycin-resistant colonies contained detectable ADH1-S activity. The percentage of transformants expressing the Adh1-S gene was not affected by the orientation of the gene relative to the $\mathrm{kan}^{\mathrm{r}}$ marker (Table 1). Both linear and supercoiled forms of the plasmid resulted in the same frequency of calli with ADH1-S activity (Table 1) and the same frequency of calli expressing levels of ADHI-S activity greater than the endogenous (data not shown).

\section{Adhl-S copy number in stable transformants}

The copy number of Adh1-S genes in several transformants was determined to establish the relationship between the copy number of the introduced Adh1-S gene and the level of ADH1-S activity (Fig. 3). DNA was isolated from individual transformants, digested with restriction enzymes, and fractionated by agarose gel electrophoresis. Because the introduced Adh1-S gene is highly homologous to the endogenous Adh1-F gene, a

Table 1. Summary of the results from the stable introduction of the maize Adhl-S gene

\begin{tabular}{lcccc}
\hline & & & Adh1-S \\
Gene & Relative orientation & Form & $\begin{array}{c}\text { Frequency } \\
\left(\times 10^{-6}\right)\end{array}$ & $\begin{array}{c}\text { expression } \\
(\%)\end{array}$ \\
\hline AdhCaMVneo-42 & $\rightarrow \rightarrow$ & SC & $7.1 \pm 3.5$ & $18 / 24(75)$ \\
AdhCaMVneo-42 & $\rightarrow \rightarrow$ & Lin & $5.1 \pm 2.8$ & $10 / 14(71)$ \\
AdhCaMVneo-43 & $\rightarrow \leftarrow$ & SC & $4.7 \pm 3.3$ & $6 / 10(60)$ \\
AdhCaMVneo-43 & $\rightarrow \leftarrow$ & Lin & $2.0 \pm 2.0$ & $6 / 8(75)$ \\
CaMVNEO & & Sc & $11.0 \pm 2.5$ & \\
CaMVNEO & & Lin & $13.5 \pm 10.5$ & \\
0 DNA & & $<0.125^{\mathrm{a}}$ & \\
\hline
\end{tabular}

The gene introduced into cultured BMS maize protoplasts is shown in the left-hand column. The relative orientation designates the relationship between the two transcription units on the plasmid; the arrow points in a $5^{\prime}$ to $3^{\prime}$ direction. SC refers to supercoiled and Lin to linear, representing the two different forms of the plasmid introduced. The frequency of transformation is represented as the mean and standard error of the number of transformants obtained per input protoplast in three separate experiments. Because the plating efficiency of these cells is low, the transformation frequency is $10^{-3}$ to $10^{-4}$ per surviving protoplast. The last column tabulates the fraction of kanamycin-resistant colonies that have detectable ADHI-S activity as assayed on native protein gels.

${ }^{a}$ No kan ${ }^{\mathrm{r}}$ calli observed in $8 \times 10^{6}$ treated protoplasts. 


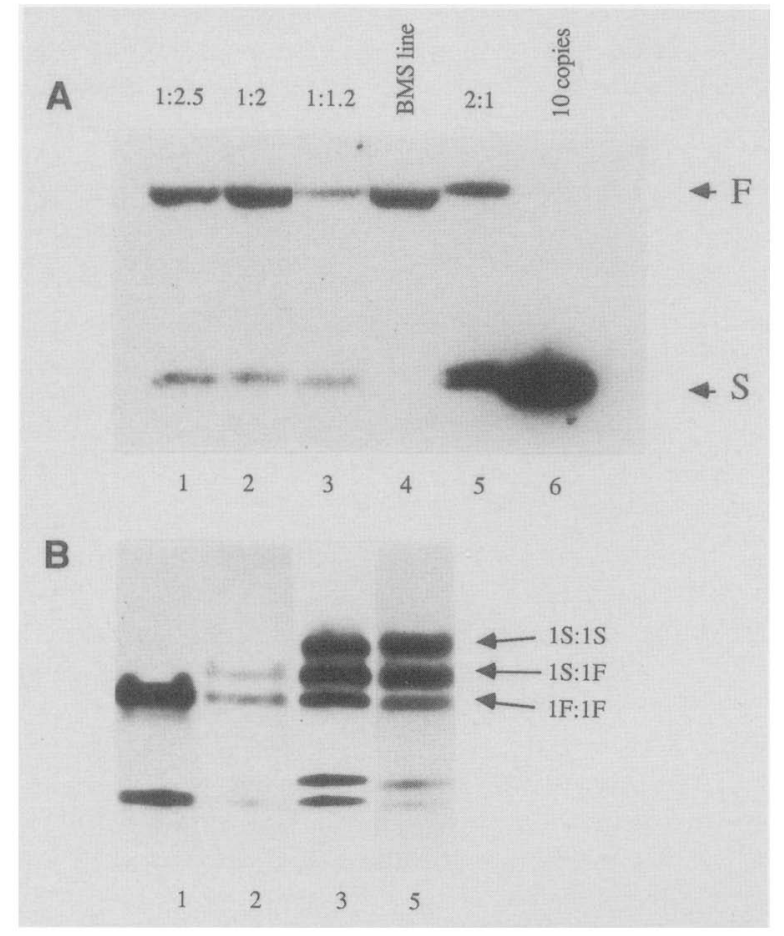

Figure 3. (A) Southern analysis of selected transformants. (F, S) BglII-XhoII DNA restriction fragments that correspond to the Adh1-F and Adh1-S genes, respectively. (Lane 4) Hybridization pattern for the BMS cell line; (lane 6) hybridization pattern of pB428 (Bennetzen et al. 1984), the Adh1-S gene. Genomic DNA from individual transformants $(10 \mu \mathrm{g})$ was run in lanes 1,2,3, and 5. The relative intensities of hybridization indicating the relative gene copy number, are above the lanes and expressed as an S:F ratio. (B) $\mathrm{ADH}$ activity gel for the transformants shown in Fig. 3A. The lane designations are as in $A$.

restriction fragment length polymorphism difference was used to distinguish the two genes (Sachs et al. 1986). The hybridization pattern of the Adh1-F gene present in the BMS cell line after hybridization of genomic DNA with an internal BglII restriction enzyme fragment from the Adh1-S gene is shown in Figure 3 (lane 4). The hybridization pattern of the Adh1-S gene is shown in Figure 3 (lane 6). The results from several transformants are shown in lanes $1,2,3$, and 5 . The relative intensity of hybridization to the Adh1-S- and the Adh1-F-specific bands was quantitated by densitometry, and the ratio is shown above the corresponding lanes, expressed as an $S: F$ ratio. The copy number of the Adh1-S gene in these transformants was low, with 1 (lanes 1 and 2) to 4 (lane 5) copies per cell.

Figure 3B shows the ADHl activity from protein extracts of the same four transformants shown in Figure 3A (the lane designations in Fig. 3B are the same as in Fig. 3A). There was a correlation between the number of Adh1-S genes determined by Southern analysis (Fig. 3A) and the level of ADH1-S enzyme activity (Fig. 3B). Figure 3A (lane 3) shows a transformant containing a Adh1-S copy number equal to that of the endogenous gene; Figure 3B (lane 3) shows that this transformant ex- presses ADH1-S activity at a level approximately equal to that of the endogenous gene. A transformant with only a single introduced gene per cell expresses less $\mathrm{ADH} 1-\mathrm{S}$ activity than the endogenous diploid gene (Fig. $3 \mathrm{~A}, \mathrm{~B}$, lane 2), whereas another transformant containing twice as many copies of the $S$ allele than the endogenous $\mathrm{F}$ allele expresses more $\mathrm{S}$ protein than $\mathrm{F}$ (Fig. 3A,B, lane 5). Transformants that do not express any ADH1-S activity (Fig. 3B, lane 1) fall into two classes, those that do not contain the expected Adh1-S BglII fragment (data not shown) and ones that do (Fig. 3A, lane 1). Because this fragment does not contain all of the coding region, the simplest explanation is that for those transformants containing this fragment but not expressing ADH1-S activity, the gene is disrupted outside of this fragment, but within sequences required for expression. Southern analysis of genomic DNA isolated from an additional nine transformants confirm the correlation between copy number and ADH1-S activity (data not shown); only one apparent exception among a total of 13 transformants analyzed was found.

\section{Structure and expression of an Adh1CAT chimeric gene}

The results from stable transformation of the maize Adh1-S gene indicated that all the regulatory sequences required for expression in cultured cells were present on the transfected DNA. The readily detectable levels of $\mathrm{ADH} 1$ activity suggested that the promoter might be useful to produce high levels of expression of other coding regions. The ability of the Adh1-S promoter to direct the expression of the CAT coding region was tested by the construction of an AdhICAT gene, $\mathrm{pACI}_{8,9} \mathrm{~A}$ (see Fig. 6 below, line 2). $\mathrm{pACI}_{8,9} \mathrm{~A}$ was derived from the Adh1-S gene (Figs. 1 and 6, line 1 for reference) by constructing an internal deletion with a $5^{\prime}$ boundary 27 nucleotides upstream of the Adh1 AUG initiation codon position and a $3^{\prime}$ boundary 28 nucleotides into the eighth exon (removing nucleotides 73-2551; for Adh1 nucleotide numbers, see Dennis et al. 1984). The remaining DNA was a 1.2-kb promoter fragment with 81 bp of the 108-bp transcribed leader (Ellis et al. 1987) and a 7.9-kb 3' Adh1 region containing introns 8 and 9 and the Adh1 polyadenylation and $3^{\prime}$-flanking region (Fig. 6, line 2). The end points of the deletion were modified with BglII linkers that served as an insertion site for the 790-bp CAT coding region.

The expression of the $\mathrm{pACI}_{8,9} \mathrm{~A}$ was determined by using an transient expression assay following electroporation-mediated gene transfer (Fromm et al. 1985, 1987). The inclusion in the electroporation solution of a second unlinked expression plasmid served as a cotransfer plasmid to control for DNA transfer efficiency, cell viability, and extract preparation. In the case of CAT chimeric genes the second plasmid expressed the firefly (Photinus pyralis) luciferase gene (de Wet et al. 1987). A chimeric CAT gene, pCaMVCN (Fig. 6, line 14), that utilized the 430-bp cauliflower mosaic virus (CaMV) $35 \mathrm{~S}$ promoter region was used as a positive control for CAT expression in maize protoplasts. This construct 
was similar to PCaMVCAT, which has been expressed in maize protoplasts (Fromm et al. 1985), except that the 3 ' Nos polyadenylation region was shortened to $248 \mathrm{bp}$ as described (Fromm et al. 1986). The shorter Nos 3' polyadenylation region gave a fourfold higher expression than the previous 1123-bp Nos 3' polyadenylation region (data not shown).

An autoradiograph of a CAT activity assay produced from $\mathrm{pACI}_{8,9} \mathrm{~A}$ and $\mathrm{pCaMVCN} 36 \mathrm{hr}$ after electroporating the plasmid DNAs into maize protoplasts is shown in Figure 7 (below). The quantitative results are presented in Table 3. The pCaMVCN gene expressed 167 fold more CAT activity than the $\mathrm{pACI}_{8,9} \mathrm{~A}$ gene (see Table 3 below, line 7). CAT expression from the $\mathrm{pACI}_{8,9} \mathrm{~A}$ gene was threefold above background levels for 30- min reactions. This level of expression was at least 1000 -fold less than expected if the assumption is made that the amount of CAT protein produced from the pACI ${ }_{8,9} \mathrm{~A}$ gene should be equivalent to the amount of ADH1-S protein produced from a transfected Adh1-S gene (Fig. 2). The magnitude of the difference between the expected levels and those observed suggested some critical portion of the Adh1-S gene was missing from $\mathrm{pACI}_{8,9} \mathrm{~A}$.

Transient expression of the maize Adh1-S coding region requires introns

To determine whether internal regions of the maize Adh1-S gene were required for significant levels of expression, we analyzed the expression of the intact Adh1$S$ gene and several intron deletion Adh1-S genes in a transient assay. ADH1-S activity in protoplast extracts was quantitated after native gel electrophoresis and an in situ enzyme assay as described above for the stable Adh1-S transformants. In Figure 1 (lines 2-7) are the structures of the Adh1 genes used in the transient experiments. To facilitate plasmid constructions, the $3^{\prime}$ end of the Adh1-S gene used for stable transformation was shortened; pAdhgA (Fig. 1, line 2) contains $2.4 \mathrm{~kb}$ of 3' Adh1 sequence, about $3.0 \mathrm{~kb}$ less than the parent 11.5-kb BamHI fragment. This 3' deletion did not have a significant effect on the level of ADH1-S activity (data not shown). Figure 4 (lane 1) shows that $48 \mathrm{hr}$ after introduction of pAdhgA, in addition to the endogenous $\mathrm{ADH} 1-\mathrm{F}$ activity present in these protoplasts, there are detectable levels of ADH1-S activity. The relative isozyme ratio is not the $1: 2: 1$ observed for the stable transformants. We hypothesize that this altered ratio is a result of two factors; first, not all of the protoplasts take up exogenous plasmid and express ADH1-S activity. Second, introduction of multiple copies of the plasmid into a single protoplast results in an overproduction of the $S$ polypeptide relative to the $F$ polypeptide and, therefore, an underrepresentation of the S:F heterodimer.

Electroporation of maize protoplasts with an Adh1-S gene in which the genomic coding region has been replaced by cDNA sequences (pAdhcA; Fig. 1, line 7) results in a dramatically lower level of ADH1-S activity.
pAdhgA and pAdhcA should produce identical mRNAs; they differ only in that pAdhcA does not contain any of the nine introns present in pAdhgA (Dennis et al. 1984). While extracts from protoplasts electroporated in the presence of pAdhgA reproducibly contained readily detectable levels of ADH1-S activity (Fig. 4A, lanes 1 and 2), none could be seen in extracts from protoplasts into which pAdhcA was introduced (Fig. 4A, lanes 6 and 7 ). When fivefold more extract was electrophoresed on native gels, barely visible levels of ADH1-S activity were seen (data not shown). Quantitation by densitometry tracing showed that there was at least a 50 -fold difference in the level of Adh1-S expession between pAdhgA and pAdhcA (Table 2).

The level of CAT activity in the same extracts from the expression of the cotransfer plasmid, in this case pCaMVCN (see Fig. 6 below, line 14), is shown in Figure

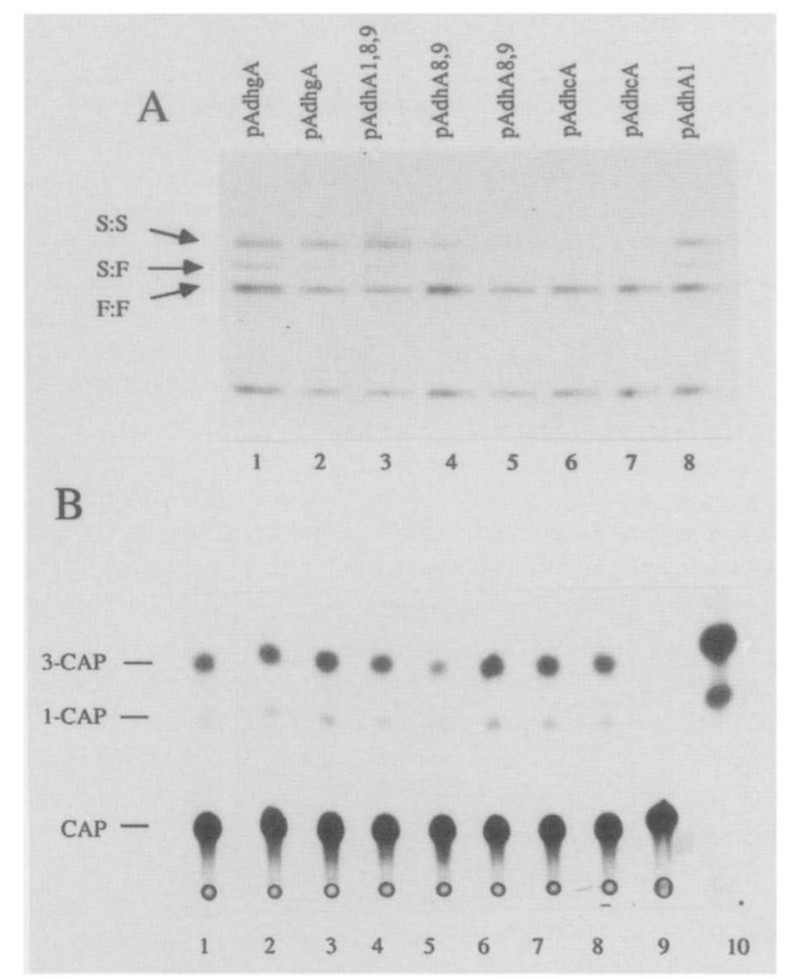

Figure 4. $(A) \mathrm{ADH}$ activity gel from transient expression of Adh1-S-containing plasmids. Plasmids containing Adhl-S genes (Fig. 1) and pCaMVCN were introduced in BMS protoplasts via electroporation and, after $48 \mathrm{hr}$ of incubation, extracts were prepared. Equal concentrations of protein $(7.5 \mu \mathrm{g})$ were loaded on a native protein gel and after electrophoresis the gel was stained for $\mathrm{ADH}$ activity. Each lane contains an aliquot of an extract from a separate electroporation. The plasmid introduced is designated above the lane. $(B)$ CAT activity in protoplasts. The same extracts shown in Fig. 4A were assayed for CAT activity and an autoradiograph of the resulting TLC plate, which separates the substrate, CAP $\left(\left[{ }^{14} \mathrm{C}\right]\right.$ chloramphenicol $)$ from the monoacetylated reaction products (1-CAP and 3-CAP), is shown. The lane designations are as in Fig. 4A. (Lane 9) CAT reaction without any maize extract; (lane 10) products produced by a bacterial extract containing pBR325 to indicate the migration of the acetylated products. 
Table 2. Effect of internal deletions on the transient expression of Adh1-S genes

\begin{tabular}{lcc}
\hline & \multicolumn{2}{c}{ ADH1-S activity } \\
\cline { 2 - 3 } Gene & $\begin{array}{l}\text { Percent } \\
\text { F expression }\end{array}$ & $\begin{array}{l}\text { Percent } \\
\text { total protein }\end{array}$ \\
\hline 1. AdhgA & 100 & 100 \\
2. AdhcA & $<0.7$ & $<2$ \\
3. AdhA1-7 & 86 & 97 \\
4. AdhA8,9 & 31 & 37 \\
5. AdhA1,8,9 & 144 & 93.5 \\
6. AdhAl & 71 & 96.5 \\
7. pAdhgA & 100 & 100 \\
8. p35SgA & 599 & 200 \\
9. p35ScA & $\mathrm{ND}$ & $\mathrm{ND}$ \\
10. p35SA8,9 & 34 & 31 \\
11. p35SA1 & 111 & 65 \\
12. pAdhgA & 100 & \\
13. pAdhxgA & 126 & \\
14. pAdhxA8,9 & 32 & \\
15. pAdhxAl,8,9 & 228 & \\
\hline
\end{tabular}

The results from a typical experiment are listed in Table 2 . The levels of expression were either normalized to the level of the endogenous ADH1-F activity present in the same extract and then normalized to pAdhgA, the Adh1-S gene containing all nine introns (column 1) or, because equal protein was loaded on each gel, the scanned value was expressed relative to pAdhgA directly (column 2). Each experiment was normalized to the level of expression of pAdhgA found in the same experiment. Each experiment was repeated twice with similar results.

${ }^{a} \mathrm{ND}$, not detectable.

4B. CAT activity levels between extracts from protoplasts into which pAdhgA and pAdhcA were introduced were nearly identical (compare Fig. 4B, lanes 1 and 2 to lanes 6 and 7). Therefore, the lack of ADH1-S activity in extracts from protoplasts electroporated in the presence of pAdhcA was not the result of inefficient gene transfer or the inability to express introduced DNA. The reduction in pAdhcA expression relative to pAdhgA is specific to the cDNA substitution.

\section{Expression of Adhl-S does not require all nine introns}

To determine whether all nine of the introns in the $A d h 1-S$ gene are required for expression, $A d h 1$ genes containing a subset of the nine introns were constructed by substitution of genomic sequences by their corresponding cDNA sequences (Fig. 1). pAdhA1-7 (Fig. 1, line 3 , which contains the first seven introns, expresses at the same level as pAdhgA, which contains all nine introns (Table 2). When pAdhA8,9 (Fig. 1, line 6), which contains only introns 8 and 9 , was introduced into maize protoplasts, there was threefold less ADHl-S activity than that produced in protoplasts from pAdhgA (Fig. 4A, lanes 4 and 5; Table 2). The CAT activity from these extracts is shown in the corresponding lanes in Figure $4 \mathrm{~B}$, again indicating that the differences in the level of ADH1-S activity were not the result of differences in gene transfer. The small difference in ADH1-S expression between Figure 4, lanes 4 and 5, however, was the result of differences in gene transfer and expression between duplicate samples (compare CAT assays, Fig. 4B, lanes 4 and 5).

The inability of the Adh1-S gene containing only introns 8 and 9 to restore full activity could be the result of a requirement for a minimum number of introns or a requirement for introns at the $5^{\prime}$ end of the gene. The effect of position was tested by adding the first intron to pAdhA8,9 to form pAdhA1,8,9 (Fig. 1, line 4). The level of ADH1-S activity resulting from the introduction of this plasmid is shown in Figure 4A (lane 3). The addition of intron 1 to pAdhA8,9 increased the level of Adh1-S expression 2- to 4.6- fold (Table 2). However, the level of ADH1-S activity from an Adh1-S gene containing only intron 1, pAdhAl (Fig. 1, line 6), produced ADH1-S activity two- to threefold higher (Fig. 4A, lane 8; Table 2) than that produced by pAdhA8,9. This suggested that there was not a requirement for multiple introns, but a specific requirement for the presence or position of the first intron.

The intron dependence for expression does not require the Adhl-S promoter

An Adh1-S gene that deleted the Adh1-S promoter region was made as a control to demonstrate that Adh1-S expression depends on the presence of a defined promoter. This construct, pgA, did not produce detectable $\mathrm{ADH}$-S activity after introduction into BMS protoplasts (Fig. 5, lane 12), indicating that the production of ADH1-S activity was dependent on the presence of the Adh1 promoter and that the observed ADH1-S activity from other Adh1-S genes was not the result of spurious transcription initiation from bacterial plasmid sequences.

The Adh 1 promoter was replaced by the 35 s promoter of CaMV to determine whether the stimulation of Adh1-S expression in the presence of introns was specific to the Adh1-S promoter. The CaMV promoter should direct efficient transcription of a downstream Adh1-S coding region regardless of the presence or absence of introns. The CaMV $35 \mathrm{~S}$ promoter was attached to two versions of the transcribed region of Adh1-S, one containing introns (p35SgA) and one containing the cDNA equivalent (p35ScA). Figure 5 (lane 1) shows that introduction of the p35SgA results in readily detectable ADHl-S activity, producing ADHl-S activity two- to fivefold higher than that produced from the introduction of pAdhgA (Table 2). In parallel with the findings for the Adh1 promoter, the cDNA equivalent, p35ScA, does not direct the synthesis of detectable ADH1-S activity (Fig. 5 , lanes 2-4; Table 2). These differences are not the result of differential protoplast expression as assayed by CAT activity (data not shown). Consequently, the requirement for introns for significant levels of expression is not specific to the Adh1-S promoter.

The first intron was also added to p35ScA /creating p35SA1) to test whether its presence resulted in ADH1-S activity equivalent to $\mathrm{p} 35 \mathrm{SgA}$. Although p35SA1 (Fig. 5, lanes 5 and 6) produces ADH1-S activity three- to sixfold less than that produced by p35SgA (Fig. 5, lane 1; Table 


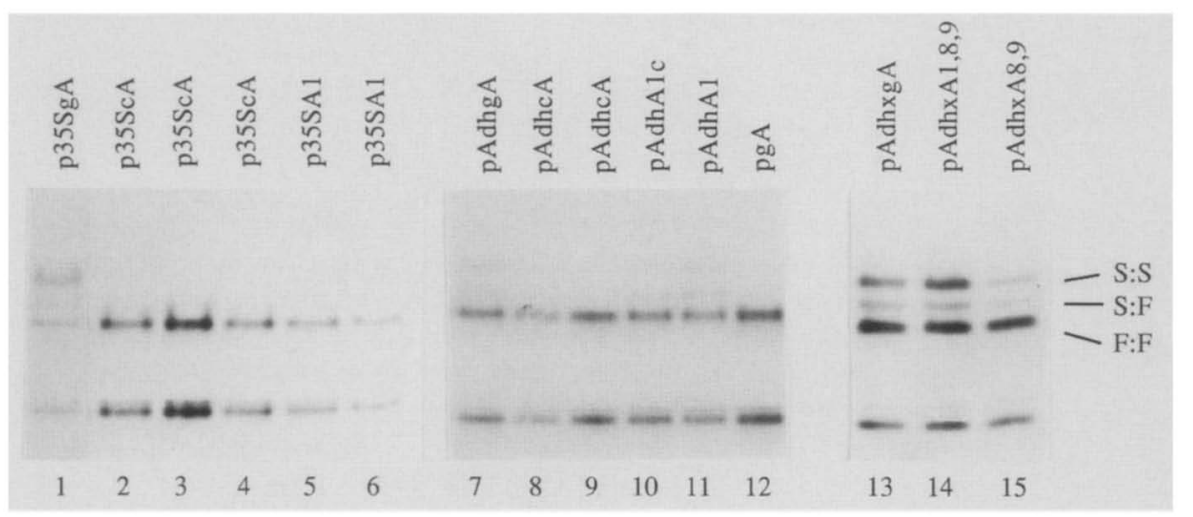

Figure 5. ADH activity gel from the transient introduction of Adh1-S genes. Experiment as described in Fig. 4A. The particular gene construct introduced is designated above the corresponding lane.
2), this level of ADH1-S activity is at least 50-fold greater than that produced by $\mathrm{p} 35 \mathrm{ScA}$ (Fig. 5, lanes 2-4; Table 2). p35SAl does result in two- to threefold more ADH1-S activity than a $35 \mathrm{~S}$ promoter-Adh1S coding region containing only the last two introns (p35SA8,9; Table 2). This difference is similar to that observed for Adh1-S genes regulated by the Adh1-S promoter with or without the first intron.

\section{Additional Adhl genes verify that intron 1 stimulates threefold more than introns 8 and 9}

Because the differences in Adh1-S expression between pAdhA 8,9 and pAdhAl, 8,9 are relatively small in magnitude, additional Adh1-S genes containing introns 8 and 9 with or without intron 1 were constructed. The results from these additional $A d h 1-S$ genes are identical, and the transient assay results from one of these sets of Adh1-S genes are shown in Figure 5 (lanes 13-15) and Table 2 (lines 12-15). These Adh1-S genes differ from the plasmids used in Figure 4A by virture of a shorter Adh1-S 5'- flanking region. This $5^{\prime}$ deletion does not affect Adh1-S expression (Table 2). The presence of the last two introns in pAdhx8,9 (Fig. 5, lane 15) results in ADH1-S activity threefold below pAdhxgA (Fig. 5, lane 13; see Table 2). The addition of the first intron to pAdhx 8,9 results in a stimulation of activity (Fig. 4, lane 14, Table 2). The reproducibility of the stimulation of $\mathrm{ADH} 1-\mathrm{S}$ activity as a result of the presence of the first intron argues strongly against the stimulation being an artifact of a particular plasmid, plasmid preparation, or protoplast preparation.

The low expression from $p A d h c A$ is not the result of a point mutation in the coding region

To control for the unlikely possibility that the very low level of expression of pAdhcA results from a mutation in its coding region that arose during plasmid construction, the $5^{\prime}$ region of pAdhcA was replaced by the $5^{\prime}$ region and first intron of pAdhgA to create pAdhAlc $/ \mathrm{c}$ for control). This plasmid was then introduced into protoplasts and the level of expression compared to that produced by the introduction of pAdhcA and pAdhAl. Figure 5 (lanes 7-11) shows the results of this experiment. pAdhAlc results in readily detectable ADH1-S activity (lane 10), similar to the level of activity from pAdhAl (lane 11). This level, as previously shown, is equivalent to that produced by pAdhgA (lane 7) and much greater than that produced by pAdhcA (lanes 8 and 9). This demonstrates that the region of pAdhcA used in this construction, which accounts for $91 \%$ of the coding sequence, is intact and codes for active ADH1-S. In addition, a similar experiment was performed using the $5^{\prime}$ region of pAdhcA and the $3^{\prime}$ region of pAdhgA, demonstrating that the $5^{\prime}$ region of pAdhcA was also intact (data not shown). These experiments confirm that the inability of pAdhcA to express ADH1-S activity is solely a result of the absence of introns in the gene.

\section{Effect of internal Adhl sequences on chimeric Adh1- CAT expression}

To determine whether internal regions of the Adh1-S gene would increase the level of CAT activity of $\mathrm{pACI}_{8,9} \mathrm{~A}$, a number of Adh1CAT constructs were made using internal regions of the Adh1 gene. The structures of these constructs are shown in Figure 6 (lines 3-7), and the corresponding CAT activities are shown in Figure 7 and in Table 3. The Adh1 promoter fragment remained the same in the entire series. $\mathrm{pACI}_{1.9} \mathrm{~A}$ (Fig. 6, line 3) contained the entire $A d h 1$ transcribed region except for a deletion extending 27 nucleotides upstream and $17 \mathrm{nu}$ cleotides downstream from the ATG initiation codon. The CAT coding region was inserted into the deleted region such that the AUG initiation codon of CAT was the first AUG in the mRNA. The remaining Adh1 region, missing from $\mathrm{pACI}_{8,9} \mathrm{~A}$, when placed downstream from CAT did not increase CAT expression $\left(\mathrm{pACI}_{1.9} \mathrm{~A}\right.$, Fig. 7 ; Table 3 , line 2 ), even though $\mathrm{pACI}_{1-9} \mathrm{~A}_{\text {contained vir- }}$ tually all the sequences present in the intact $A d h 1$ gene (Fig. 6, compare lines 1 and 3).

Because the position of introns in the intact Adh1 gene affected the level of $\mathrm{ADH}$ expression and the first intron alone was capable of restoring wild-type levels of $\mathrm{ADH}$ expression (see above), we investigated the position dependence of an $A d h 1$ intron 1 fragment in additional AdhCAT chimeric genes. Construct $\mathrm{pAI}_{1} \mathrm{CI}_{8,9} \mathrm{~A}$ was made (Fig. 6, line 4) to test whether the Adh1 intron 1 fragment when upstream from the CAT coding region, 


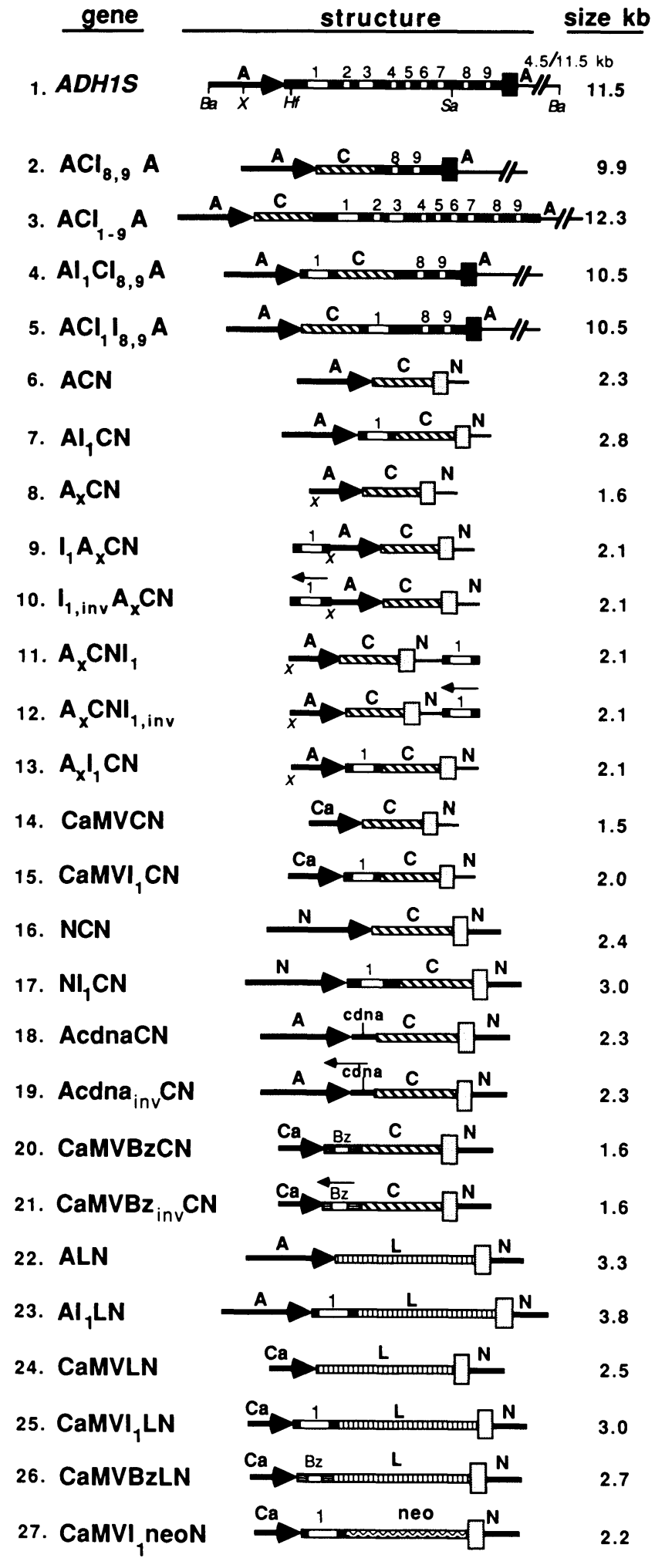

adjacent to the Adh1 promoter, would stimulate expression. $\mathrm{pACI}_{1} \mathrm{I}_{8,9} \mathrm{~A}$ was a control construct that has the same $A d h 1$ intron 1 fragment inserted downstream from the CAT gene (Fig. 6, line 5). The Adh1 intron 1 fragment stimulated transient gene expression 110-fold when located upstream from the CAT gene in construct
Figure 6. Structures of the chimeric CAT, luciferase, and Neo genes. The exact boundaries of the fragments used in the constructs are described in Material and methods. Symbols: (A) Adh1; (Bz) Bronze1 intron; (C) CAT; (Ca) CaMV; (cdna) Adh1 intron 1 cDNA equivalent; (L) luciferase; (N) Nos; (neo) neomycin phosphotransferase II. Restriction sites: (Ba) BamHI; (X) XbaI; (Hf) HinfI; (Sa) SalI. Adh1 (A) and CaMV (Ca) promoters are represented as large rightward arrows and the Adh1 (black) and Nos (stippled) 3' polyadenylation regions are represented as the short vertical rectangles. The transcribed Adh1 exons (black) and introns (white with intron number above) of the CAT (striped), luciferase (vertical lines), and Neo (wavy lines) coding regions are represented as the long horizontal rectangles. The antisense direction of the $A d h 1$ intron 1 fragment and $B z 1$ intron fragment is indicated by the small leftward arrow located above them. The Adh1 3'-flanking region is represented by the thin line and the diagonal slashes indicate that the region between 4.5 and $11.5 \mathrm{~kb}$ of the Adh1 gene is present but not drawn out. The size of the transcription unit is indicated in kilobase pairs $(\mathrm{kb})$. The actual plasmids containing the transcription units are $2.7 \mathrm{~kb}$ larger than indicated, from the contribution of pUC8 plasmid vector sequences.

$\mathrm{pAI}_{1} \mathrm{Cl}_{8,9} \mathrm{~A}$ but only fivefold when located downstream from the CAT gene in construct pACI $I_{8,9} \mathrm{~A}$ (Fig. 7; Table 3 lines 3 and 4 ).

Replacement of the Adhl polyadenylation region by the Nos polyadenylation region

Subsequent experiments were performed using the Nos 3 ' polyadenylation region, because we observed an eightfold increase in the level of CAT expression in construct ACN (Fig. 7; Table 3, line 5) in which the Nos 3' end was substituted for that of the Adh1 $3^{\prime}$ end in construct $\mathrm{pACI}_{8,9} \mathrm{~A}$ (Fig. 6, lines 2 and 6). The same stimulation by the Adh1 intron 1 fragment was apparent in constructs containing the Nos $3^{\prime}$ region. Construct $\mathrm{pAI}_{1} \mathrm{CN}$, which contains the $A d h 1$ intron 1 upstream from the CAT gene (Fig. 6, line 7), expressed 142-fold more CAT activity than the construct pACN (Fig. 7; Table 3, line 5 vs. line 6). The effects of the Adh1 intron 1 fragment and the Nos $3^{\prime}$ region are multiplicative (compare levels in Fig. 7 and in Table 3 for the series $\mathrm{pACI}_{8,9} \mathrm{~A}$ vs. pAI $\mathrm{CI}_{8,9} \mathrm{~A}$ vs. $\mathrm{pAI}_{1} \mathrm{CN}$ or the series $\mathrm{pACI} \mathrm{I}_{8,9} \mathrm{~A}$ vs. pACN vs $\mathrm{pAI}_{1} \mathrm{CN}$ ) and combined they give an overall increase in CAT expression of 1096-fold. The Nos 3' region was used in all subsequent experiments to maximize the level of expression of these chimeric genes.

The Adh 1 intron 1 fragment stimulates activity only when in the transcription unit

The ability of the Adh1 intron 1 fragment to act as an enhancer was tested by placing it upstream from the Adh1 promoter in constructs $\mathrm{pI}_{1} \mathrm{~A}_{\mathrm{x}} \mathrm{CN}$ and $\mathrm{pI}_{1, \text { inv }} \mathrm{A}_{\mathrm{x}} \mathrm{CN}$ and downstream from the Nos $3^{\prime}$ region in constructs $\mathrm{pA}_{\mathrm{x}} \mathrm{CNI}_{1}$ and $\mathrm{pA}_{\mathrm{x}} \mathrm{CNI}_{1, \text { inv }}$ (Fig. 6, lines 9-12) in both orientations at each position. A 486-bp Adh1 promoter fragment $\left(A_{x}\right)$ was used for this series of constructs, and the reference constructs $\mathrm{pA}_{\mathrm{x}} \mathrm{CN}$ and $\mathrm{pA}_{\mathrm{x}} \mathrm{I}_{1} \mathrm{CN}$ also use the 486-bp Adh1 promoter fragment (Fig. 6, lines 8 and 
Table 3. The Adhl intron 1 fragment affects CAT expression

\begin{tabular}{|c|c|c|c|}
\hline Gene & $\begin{array}{l}\text { Luciferase } \\
\text { cotransfer } \\
\text { (light units } / 10 \mathrm{sec} \text { ) }\end{array}$ & $\begin{array}{l}\text { Corrected } \\
\text { CAT activity } \\
\text { (\% acetylated) }\end{array}$ & Fold (relative to) \\
\hline \multicolumn{4}{|c|}{ Within transcribed region } \\
\hline 1. $\mathrm{ACI}_{8,9} \mathrm{~A}$ & 78,531 & 0.046 & 1.0 \\
\hline 2. $\mathrm{ACI}_{1-9} \mathrm{~A}$ & 102,163 & 0.041 & 0.9 (line 1$)$ \\
\hline 3. $\mathrm{AI}_{1} \mathrm{CI}_{8,9} \mathrm{~A}$ & 132,638 & 5.10 & 110.3 (line 1 ) \\
\hline 4. $A \mathrm{ACI}_{1} \mathrm{I}_{8,9} \mathrm{~A}$ & 94,009 & 0.24 & $5.2($ line 1$)$ \\
\hline 5. ACN & 235,957 & 0.36 & 7.7 (line 1) \\
\hline 6. $\mathrm{AI}_{1} \mathrm{CN}$ & 215,224 & 50.70 & $1096.0($ line 1$)$ \\
\hline 7. CaMVCN & 159,000 & 7.75 & 167.5 (line 1$)$ \\
\hline \multicolumn{4}{|c|}{ Outside transcribed region } \\
\hline 8. $\mathrm{A}_{\mathrm{X}} \mathrm{CN}$ & 63,208 & 0.65 & 1.0 \\
\hline 9. $\mathrm{I}_{1} \ddot{\mathrm{A}}_{\mathrm{x}} \mathrm{CN}$ & 96,664 & 0.41 & $0.6($ line 8$)$ \\
\hline 10. $\mathrm{I}_{1, \text { inv }} \mathrm{A}_{\mathrm{X}} \mathrm{CN}$ & 110,780 & 0.27 & 0.4 (line 8 ) \\
\hline 11. $\mathrm{A}_{\mathrm{X}} \mathrm{CNI}_{1}$ & 86,335 & 1.43 & 2.2 (line 8 ) \\
\hline 12. $\mathrm{A}_{\mathrm{X}} \mathrm{CNI}_{1, \mathrm{inv}}$ & 146,992 & 0.68 & 1.0 (line 8 ) \\
\hline 13. $\mathrm{A}_{\mathrm{X}} \mathrm{I}_{1} \mathrm{CN}$ & 136,287 & 46.20 & 70.8 (line 8$)$ \\
\hline \multicolumn{4}{|c|}{ Different promoters } \\
\hline 14. $\mathrm{NCN}$ & 229,243 & 0.09 & 1.0 \\
\hline 15. $\mathrm{NI}_{1} \mathrm{CN}$ & 209,250 & 15.17 & 170.1 (line 14) \\
\hline 16. ACN & 246,916 & 0.70 & 1.0 \\
\hline 17. $\mathrm{AI}_{1} \mathrm{CN}$ & 193,628 & 49.01 & 69.9 (line 16) \\
\hline 18. CaMVCN & 228,189 & 6.68 & 1.0 \\
\hline 19. $\mathrm{CaMVI}_{1} \mathrm{CN}$ & 208,291 & 56.20 & $8.4($ line 18$)$ \\
\hline
\end{tabular}

The transient expression of each construct was measured two or more times, and the results of a representative experiment are shown. CAT activity was measured as the percentage of the $\left[{ }^{14} \mathrm{C}\right]$ chloramphenicol that was acetylated in a 30 -min reaction and values were corrected to correspond to the same number of copies for each construct as present in $20 \mu \mathrm{g}$ of ACN plasmid DNA (rough \% $\mathrm{CAM} \times \mathrm{MW}$ each construct/MW ACN). The amount of luciferase expression (light units (l.u.//10 sec) was used to calculate the cotransfer corrected percentage acetylated chloramphenicol (CAT activity $\times$ average l.u./each l.u.). The fold stimulation is the ratio of the cotransfer corrected percentage of acetylated chloramphenicol produced from expression of each gene to the value for the construct indicated in parentheses.

13). The Adh1 intron 1 fragment did not significantly stimulate expression of the CAT gene when located at either the $5^{\prime}$ - or $3^{\prime}$-flanking regions, regardless of orientation (Table 3, lines 8-12). The shorter Adh1 promoter fragment used in these experiments showed a 70 -fold stimulation when the Adh1 first intron was present between the promoter and the CAT gene (Table 3, line 13). This result appears to rule out the possibility that the Adh1 intron 1 fragment contains a typical enhancer element (Fromm and Berg 1983; Ptashne 1986).

The Adhl intron 1 fragment stimulates expression in CaMV 35 and Nos promoter chimeric genes

The ability of the Adh1 intron 1 fragment to stimulate the level of CAT expression from two other promoters was examined to determine whether the effect was specific to the Adh1 promoter. The Adh1 intron 1 fragment

Figure 7. CAT activities from constructs either containing or lacking the $A d h i$ first intron. CAT assays were performed $36 \mathrm{hr}$ after electroporating protoplasts with $20 \mu \mathrm{g} / \mathrm{ml}$ of the indicated plasmid DNAs (see Fig. 6 for gene structures). An autoradiograph of a thin-layer chromatogram of the CAT assay reaction products is shown. The percentages of acetylated chloramphenicol are shown in Table 3 , lines $1-7$. was inserted between the CAT coding region and either the 430-bp CaMV 35S promoter or the 1350-bp Nos promoter (Fromm et al. 1985) to form constructs pCaMVI ${ }_{1} \mathrm{CN}$ and $\mathrm{pNI}_{1} \mathrm{CN}$, respectively (Fig. 6, lines 15 and 17). Constructs pCaMVCN and pNCN, which lack

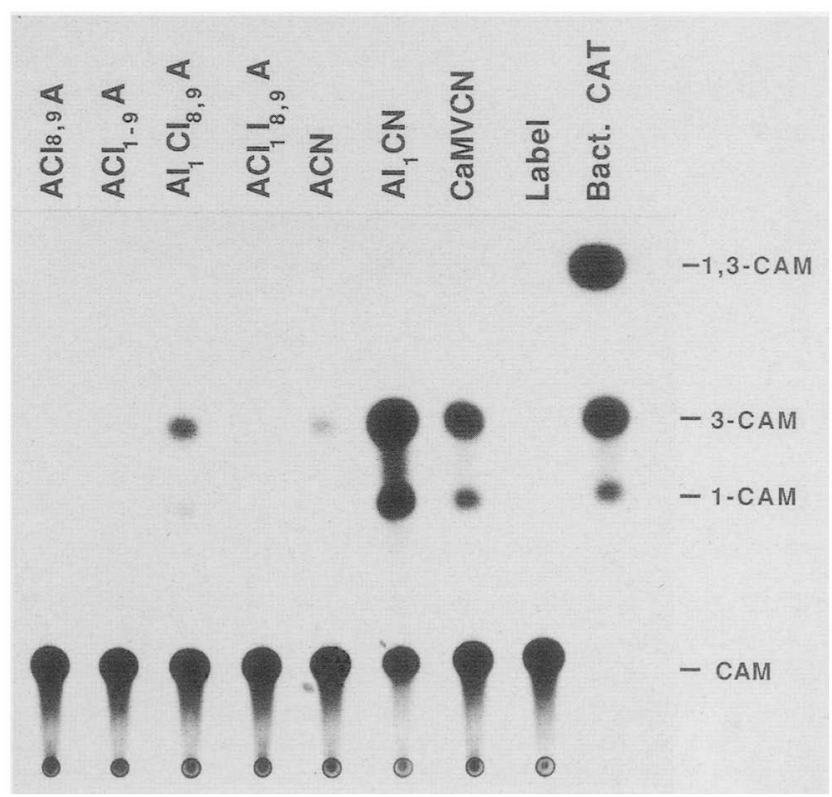


the Adh1 intron 1 fragment, serve as controls (Fig. 6, lines 14 and 16). The presence of the Adh1 intron 1 fragment stimulated transient expression 170-fold from the Nos promoter and 8-fold from the CaMV promoter (Table 3, lines 15 and 19). In this same experiment, the Adh1 intron 1 increased expression from the Adh1 promoter by 70 -fold (Table 3 , line 17). This indicated the stimulation of expression by the Adh1 intron 1 fragment was not specific to the Adh1 promoter, although the magnitude of the stimulation of CAT expression was not identical for the different promoters.

The effect of the Adhl intron fragment is not translational

Constructs pACN and $\mathrm{pAI}_{1} \mathrm{CN}$ produced slightly different mRNAs as a result of the 23 nucleotides of exon sequence in $\mathrm{pAI}_{1} \mathrm{CN}$ mRNA that are left behind after intron 1 was spliced out. These 23 nucleotides in the mRNA 5' leader could favorably alter the translation efficiency or RNA stability of the RNA produced from $\mathrm{pAI}_{1} \mathrm{CN}$. Therefore, the effect of the exon sequences was tested by substituting a 23-oligonucleotide "cDNA" into the same position as intron 1 in $\mathrm{pAI}_{1} \mathrm{CN}$ to form pAcdnaCN (Fig. 6, line 18). pAI ${ }_{1} \mathrm{CN}$ and pAcdnaCN should produce identical mRNAs if the RNA from $\mathrm{pAI}_{1} \mathrm{CN}$ was spliced as predicted. Thus, if the stimulation from the Adh1 intron 1 fragment was the result of the $23 \mathrm{bp}$ in the flanking exon sequences, then pAcdnaCN should express CAT activity as well as construct $\mathrm{pAI}_{1} \mathrm{CN}$. Alternatively, if the stimulation was a result of the sp.icing of intron 1 or sequences within intron 1 , then the expression of pAcdnaCN should be equivalent to that of pACN, which lacks the entire $A d h 1$ intron 1 fragment (Fig. 6, line 6). The latter result was obtained from transient expression of these constructs (Table 4, lines 1,2, and 4). The increase in expression resulting from the addition of the exon sequences in construct pAcdnaCN was only $3 \%$ of the intron effect (Table 4 , line 2 vs. line 4). The antisense direction of the cDNA insert in construct pAcdna $a_{\text {inv }} \mathrm{CN}$ (Fig. 6, line 19) produced CAT activity similar to that of pACN (Table 4, line 3). Thus, the exon sequences contribute only $3 \%$ of the intron fragment effect. Therefore, the effect of the Adh 1 intron 1 fragment was apparently not at the level of translation efficiency or cytoplasmic mRNA stability, because the final mRNA structures produced from pAcdnaCN and $\mathrm{pAI}_{1} \mathrm{CN}$ should be identical. RNA mapping indicated that $\mathrm{pAI}_{1} \mathrm{CN}$ RNA had the expected structure (see below).

\section{The Adhl intron fragment affects mRNA levels}

The amounts and structures of the mRNAs produced from pAcdnaCN and $\mathrm{pAI}_{1} \mathrm{CN}$ were determined by RNase protection assays (Fig. 8). BMS maize protoplasts were electroporated in the presence of $25 \mu \mathrm{g} / \mathrm{ml}$ of cotransfer control pCaMVBzLN DNA and $50 \mu \mathrm{g} / \mathrm{ml}$ of either pAcdnaCN or $\mathrm{pAI}_{1} \mathrm{CN}$ DNA. After $24 \mathrm{hr}$, extracts were prepared from an aliquot of the protoplasts and RNA was isolated from the remainder of the protoplasts. The extracts showed similar luciferase activities indicating that equivalent DNA transfer occurred for both DNAs; however, pAI ${ }_{1} \mathrm{CN}$ extracts produced 30 -fold more CAT activity than pAcdnaCN extracts /data not shown). This was consistent with the 34 -fold increase in CAT activity observed earlier (Table 4).

RNase protection assays were then performed on aliquots of the RNA samples to determine the amount and the $5^{\prime}$ ends of the CAT mRNAs produced from pAcdnaCN and $\mathrm{pAI}_{1} \mathrm{CN}$. The structure of the radioactive RNA 5' end probe, $A_{x} c d n a C_{R}$, is shown in Figure 8B. This probe was derived from pAcdnaCN (Fig. 6, line 18) and spans the $A d h 1$ promoter- cDNA-CAT 5 ' region. If pAcdnaCN and pAI ${ }_{1} \mathrm{CN}$ mRNAs have $5^{\prime}$ ends at the same position as the normal Adh1 mRNA, then both should protect a 365-nucleotide fragment after hybridization and RNase digestion. RNA from $\mathrm{pAI}_{1} \mathrm{CN}$ will protect a 365-nucleotide fragment only if the Adh1 intron 1 was spliced properly; unspliced RNA would protect fragments that are 97 and 267 nucleotides long. Both pAcdnaCN and $\mathrm{pAI}_{1} \mathrm{CN}$ RNAs protected the expected 365-nucleotide region (Fig. $8 \mathrm{~A}, \mathrm{~A}_{\mathrm{X}} \mathrm{C}_{\mathrm{R}} 5^{\prime}$ probe lanes), indicating that the correct RNA initiation site was used for both and that correct splicing occurred in the RNA from $\mathrm{pAI}_{1} \mathrm{CN}$. This indicated that the 5 ' ends

Table 4. Characterization of the Adhl intron 1 effect by substitution

\begin{tabular}{|c|c|c|c|}
\hline Gene & $\begin{array}{l}\text { Luciferase } \\
\text { cotransfer } \\
\text { (light units/10 sec) }\end{array}$ & $\begin{array}{l}\text { Corrected } \\
\text { CAT activity } \\
\text { (\% acetylated) }\end{array}$ & Fold (relative to) \\
\hline \multicolumn{4}{|l|}{ Adh1 cDNA vs. intron } \\
\hline 1. ACN & 6,364 & 0.40 & 1.0 \\
\hline 2. AcdnaCrN & 6,972 & 1.30 & 3.3 (line 1) \\
\hline 3. $\operatorname{Acdn} ?_{\text {inv }} \mathrm{CN}$ & 10,510 & 0.63 & 1.6 (line 1) \\
\hline 4. $\mathrm{AI}_{1} \mathrm{CN}$ & 9,708 & 44.34 & 112.2 (line 1) \\
\hline \multicolumn{4}{|c|}{$A d h 1$ intron vs. $B z 1$ intron } \\
\hline 5. CaMVCN & 37,692 & 1.75 & 1.0 \\
\hline 6. $\mathrm{CaMVI}_{1} \mathrm{CN}$ & 38,947 & 38.20 & 21.8 (line 5) \\
\hline 7. $\mathrm{CaMVBzCN}$ & 35,563 & 10.84 & 6.2 (line 5) \\
\hline 8. $\mathrm{CaMVB} z_{\text {inv }} \mathrm{CN}$ & 30,136 & 0.12 & 0.07 (line 5) \\
\hline
\end{tabular}

As in legend to Table 3. 

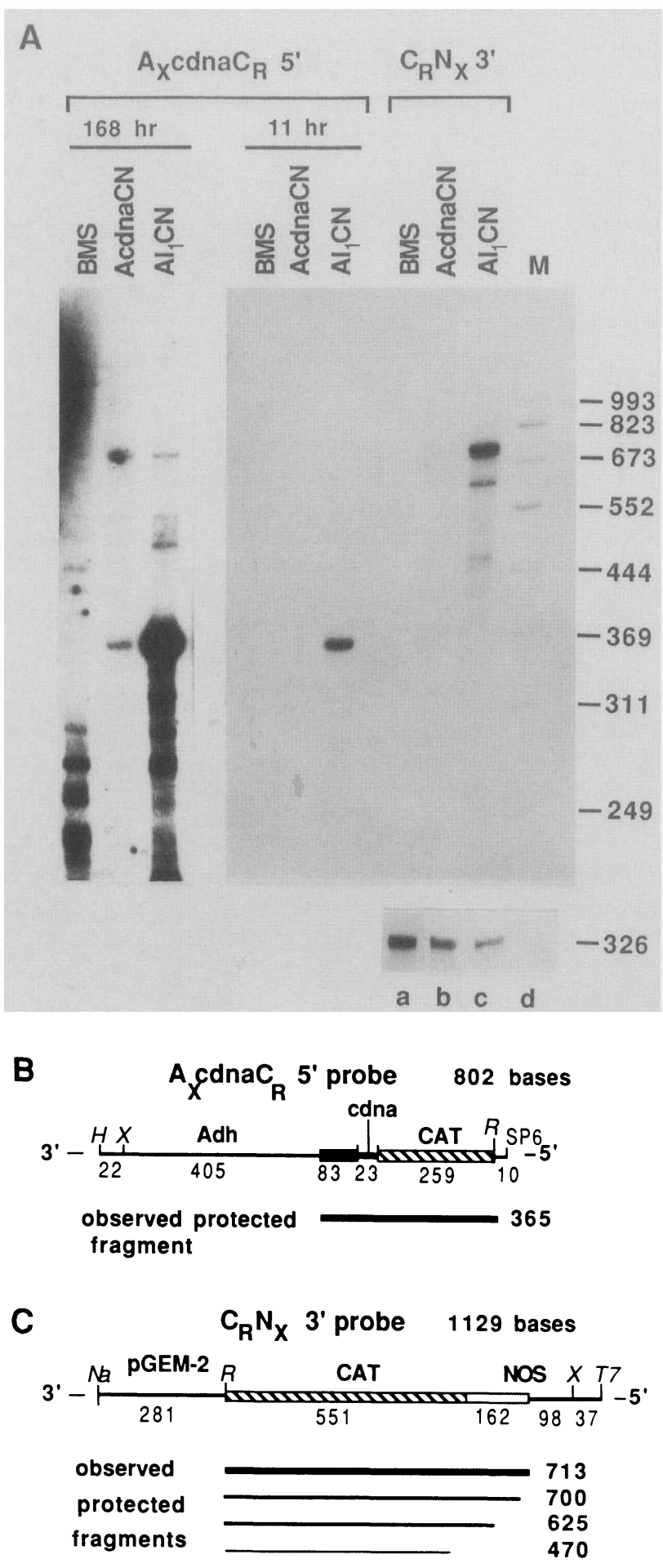

of the transcript from $\mathrm{pAI}_{1} \mathrm{CN}$ and $\mathrm{pAcdnaCN}$ were the same. Consistent with the lower CAT activity, there is approximately 40 -fold less of the 365 -nucleotide fragment protected by mRNA from pAcdnaCN (Fig. 8A, 168-hr exposure).

The $3^{\prime}$ ends of the RNAs from pAcdnaCN and $\mathrm{pAI}_{1} \mathrm{CN}$ were mapped by using the $\mathrm{C}_{\mathrm{R}} \mathrm{N}_{\mathrm{X}} 3^{\prime}$ probe whose structure is shown in Figure $8 \mathrm{C}$. If pAcdnaCN and $\mathrm{pAI}_{1} \mathrm{CN}$ mRNAs $3^{\prime}$ ends occurred at the same position as the
Figure 8. Amount and structure of pAcdnaCN and $\mathrm{pAI}_{1} \mathrm{CN}$ mRNAs. An autoradiograph of the RNA probe fragments protected after hybridization to total RNA from protoplasts electroporated with pAcdnaCN or $\mathrm{pAI}_{1} \mathrm{CN}$ DNA, and subsequently digested with RNase and electrophoresed through a denaturing gel is shown in $A$. Schematic representations of the RNA probes used to map the pAcdnaCN and $\mathrm{pAI}_{1} \mathrm{CN}$ mRNA $5^{\prime}$ and $3^{\prime}$ ends are shown in $B$ and $C$. The probe regions expected to be protected are represented as horizontal rectangles and the unprotected regions as lines. The observed protected fragments are represented below each probe schematic. Symbols: $(\mathrm{H})$ HindIII; (X) XbaI; (R) EcoRI; (Na) NaeI; (SP6) SP6 RNA polymerase initiation site; (T7) T7 RNA polymerase initiation site. $(A)$ Probe regions protected from RNase digestion after hybridization to pAcdnaCN and $\mathrm{pAI}_{1} \mathrm{CN}$ RNA. Total RNA $(20 \mu \mathrm{g})$ from nonelectroporated protoplasts (BMS lanes) as well as from BMS protoplasts electroporated with either pAcdnaCN or $\mathrm{pAI}_{1} \mathrm{CN}$ DNA was hybridized to the indicated radioactive antisense RNA probes, digested with RNase, and electrophoresed on a denaturing $4 \%$ polyacrylamide $/ 8 \mathrm{M}$ urea gel. The sizes of the denatured DNA markers ( $M$ lane) are indicated in nucleotides to the right of the figure. The insert at the bottom of $A$ shows the hybridization of the same RNA samples to the $A d h 1$ exon 4 probe. The endogenous BMS Adh1-F mRNA protects similar amounts of the expected 326-nucleotide fragment in each total RNA sample. Lanes: $(a) \mathrm{BMS}_{\text {; }}(b)$ AcdnaCN; $(c) \mathrm{AI}_{1} \mathrm{CN}$; $(d)$ yeast. $(B)$ Structure of the $A_{X} c d n a C_{R} 5^{\prime}$ probe used to map the RNA 5 'ends. The 770-bp Xbal-EcoRI fragment of pAcdnaCN was ligated into pGEM-2 to serve as a template for generating the probe shown. The template was linearized with HindIII and transcribed with SP6 RNA polymerase in the presence of $\left[\alpha^{-32} \mathrm{P}\right]$ CTP. The resulting 802 -nucleotide probe should hybridize to 83 nucleotides of the Adh1 leader region, the 23-nucleotide cDNA region, and the 259-nucleotide CAT coding region to protect a 365 -nucleotide fragment. $(C)$ Structure of the $\mathrm{C}_{\mathrm{R}} \mathrm{N}_{\mathrm{X}} 3^{\prime}$ probe used to map the RNA 3' ends. The 811-bp $X b a I-E c o R I$ fragment of AcdnaCN was ligated into pGEM-2 to serve as a template for generating the probe shown. The template was linearized with NaeI and transcribed with T7 RNA polymerase. The resulting 1129-nucleotide probe should hybridize to the 551-nucleotide CAT coding region and $162 \mathrm{nu}$ cleotides of the Nos $3^{\prime}$ poly (A) region. This should produce a 713-base protected region. After hybridization of the probe to the various RNAs indicated, followed by RNase digestion and gel electrophoresis, the major abundant $3^{\prime}$ end $(720+/-15$ nucleotides) appeared to occur at the normal Nos poly(A) site. Additional minor bands appeared to have the $3^{\prime}$ indicated.

Nos RNA 3' end position (DePicker et al. 1982; Bevan et al. 1983a), then a 713-nucleotide protected fragment is expected. This was the major band protected by both the pAcdnaCN and $\mathrm{pAI}_{1} \mathrm{CN}$ RNAs (Fig. $8 \mathrm{~A}, \mathrm{C}_{\mathrm{R}} \mathrm{N}_{\mathrm{X}} 3^{\prime}$ probe lanes). In parallel with the study of $5^{\prime}$ ends, long exposures were required to detect the AcdnaCN signal (data not shown). The regions protected by the additional minor bands observed are indicated in Figure 8C.

As a control for RNA recovery and hybridization, aliquots of the isolated RNA were analyzed for the amount of endogenous Adh1-F mRNA. These measurements were also used to establish that the endogenous Adh1-F gene was being expressed at equivale: $:$ ? evels in the two populations. A 689-nucleotide RNA probe complementary to the region spanning Adh1 exon 4 and flanking introns (Adh1 nucleotides 2409-3061) was used to 
quantitate the amount of endogenous Adh1-F mRNA. A 326-nucleotide fragment was expected to be protected by exon 4 (Dennis et al. 1984). This fragment was observed after hybridization to $20 \mu \mathrm{g}$ of total RNA from the pAcdnaCN and $\mathrm{pAI}_{1} \mathrm{CN}$ samples, followed by RNase $\mathrm{A}$ and $\mathrm{T} 1$ digestion, and denaturing gel electrophoresis (Fig. 8A, lanes $\mathrm{b}$ and $\mathrm{c})$. RNA from untransformed BMS maize protoplasts (lane a) and yeast RNA (lane d) served as positive and negative controls, respectively (Fig. 8A).

The $5^{\prime}$ and $3^{\prime}$ protection results indicated that the CAT RNAs had the expected termini at the normal Adh1 5' and Nos 3' RNA end positions, that the Adh1 intron 1 fragment in RNA from $\mathrm{pACI}_{1} \mathrm{CN}$ was spliced properly, and that the difference in CAT enzymatic activity was the result of the difference in mature mRNA levels produced by pAcdnaCN and $\mathrm{pAI}_{1} \mathrm{CN}$. Therefore, sequences within intron 1 appeared to be responsible for the increased levels of expression observed. This could be the result of increased transcription or could be related to the efficiency of pre-mRNA processing or transport.

\section{The maize Bronzel intron also stimulates CAT activity}

Whether the stimulation of CAT activity by the Adh1 intron fragment was specific to this intron was tested by substituting an intron from different maize gene, Bronze1 (Bz1). This gene codes for the enzyme UDPglucose:flavonol glucosyl-transferase, a terminal step in the anthocyanin pigment pathway of maize (Dooner and Nelson 1977). The isolated $B z 1$ gene (Fedoroff et al. 1984) has been sequenced (Furtek 1986) and contains a single 99-bp intron. The 156-bp HpaII fragment containing the $B z 1$ intron contains no ATGs in the exon portions of the fragment. This fragment was inserted between the CaMV 35S promoter and the CAT gene to yield construct $\mathrm{pCaMVBzCN}$ and $\mathrm{pCaMVBz} \mathrm{inv}_{\mathrm{inv}} \mathrm{CN}$ (Fig. 6 , lines 20 and 21). The antisense orientation pCaMVB$z_{\text {inv }} \mathrm{CN}$ (Fig. 6, line 21) served as a control for splicing of the sense orientation of the $B z 1$ intron because a lack of splicing would result in an identical mRNA leader length. Transient expression assays of these constructs showed that the presence of the $B z 1$ intron fragment in the sense orientation increased CAT expression 6.2-fold in construct pCaMVBzCN (Table 4, line 7) but reduced expression 14-fold in the antisense orientation in pCaMVBzl $1_{\text {inv }} \mathrm{CN}$ (Table 4, line 8 ), relative to the pCaMVCN construct lacking the $B z 1$ fragment (Table 4, line 5). The observed polarity indicates that the $B z 1$ intron is spliced when inserted in the sense orientation. The 6.2-fold stimulation by the $B z 1$ intron was less than the 21.8-fold stimulation observed in this experiment when the Adh1 intron fragment was used in construct $\mathrm{pCaMVI}_{1} \mathrm{CN}$ (Table 4, line 6).

Both the Adh1 intron 1 and the Bzl intron stimulate luciferase expression

The effect of the Adh1 and $B z 1$ intron fragments on the expression of two additional coding regions, Neo (see below) and the firefly luciferase (de Wet et al. 1987) was assayed to determine the specificity of the intron stimulation. Both introns were inserted upstream of the luciferase cDNA coding region. The Adh1 intron 1 fragment was used with both the Adh1 and CaMV $35 S$ promoters to form constructs $\mathrm{pAI}_{1} \mathrm{LN}$ and $\mathrm{pCaMVI}_{1} \mathrm{LN}$, respectively (Fig. 6, lines 23 and 25). The two control constructs lacking the intron fragment were pALN and pCaMVLN (Fig. 6, lines 22 and 24). The Bz1 intron was tested with the CaMV $35 \mathrm{~S}$ promoter to form construct pCaMVBzLN (Fig. 6, line 26) and was also compared to pCaMVLN as a reference point.

The results of a typical transient expression assay using these constructs are shown in Table 5 (lines 1-5). The Adh1 intron 1 fragment stimulated luciferase expression 15.8-fold when using the Adh1 promoter (Table 5 , line 2) and 5.1-fold when using the CaMV promoter (Table 5, line 4). The $B z 1$ intron fragment increased luciferase expression 5.8-fold when expressed from the CaMV 35S promoter (Table 5, line 5). These results indicated that the $B z 1$ intron stimulated expression of coding regions to approximately the same extent as the Adh1 intron 1 fragment. This suggested that the effects of the two intron fragments were similar.

\section{The Adhl intron fragment stimulates neomycin phosphotransferase II expression}

The Adh1 intron 1 fragment was tested for its ability to increase the level of expression from the neo gene (Beck et al. 1982; Southern and Berg 1982). Two constructs using the CaMV $35 \mathrm{~S}$ promoter, the Neo coding region, and the Nos 3 ' polyadenylation region were compared. pCaMVI ${ }_{1}$ neoN contains the Adh1 intron fragment between the promoter and Neo coding region (Fig. 6, line 27) while pCaMVNEO lacks the Adh1 intron fragment. The transient expression of these genes was measured by an in situ gel assay procedure using kanamycin and $\left[\gamma^{-32}\right.$ P]ATP (Reiss et al. 1984) after polyacrylamide gel electrophoresis of extracts from electroporated protoplasts. The results, presented in Table 5 (lines 6 and 7), indicated that the presence of the Adh1 intron 1 fragment increased neo expression 14.6-fold.

\section{Discussion}

We show here that electroporation-mediated gene transfer can be used to stably introduce nonselected genes into plant cells by linking them to a selectable marker. This is the first example of the reintroduction and expression of a complete monocot gene into monocot cells. The copy number of stably introduced Adh1$S$ genes was generally low, and appears to be relatively insensitive to position effects. This might be a reflection of the selection procedure; it is possible that because resistance to kanamycin requires a certain level of expression, only those events where integration occurred in favorable or neutral chromosomal environments would be recovered. Stable transformants demonstrated that the 
Table 5. The presence of an intron increases the expression of the firefly luciferase and neomycin phosphotransferase II coding regions

\begin{tabular}{lccc}
\hline Gene & $\begin{array}{l}\text { Cotransfer } \\
\text { control }\end{array}$ & $\begin{array}{l}\text { Corrected } \\
\text { coding region } \\
\text { expression }\end{array}$ & Fold (relative to) \\
\hline Firefly luciferase coding region & $19.7^{\mathrm{a}}$ & $15,779^{\mathrm{b}}$ & 1.0 \\
1. ALN & 18.3 & 249,599 & 15.8 (line 1) \\
2. AI $\mathrm{L}_{1} \mathrm{LN}$ & 20.5 & 34,035 & 1.0 \\
3. CaMVLN & 26.2 & 174,525 & 5.1 (line 3) \\
4. CaMVI $\mathrm{LN}$ & 24.2 & 197,018 & 5.8 (line 3) \\
5. CaMVBzLN & & & \\
Neo coding region & $247,497^{\mathrm{c}}$ & 2,998 & 1.0 \\
6. CaMVneoN & 251,506 & 43,856 & 14.6 (line 6) \\
7. CaMVI & neoN &
\end{tabular}

As in legend to Table 3 except that CAT activity from pCaMVCN serves as the DNA cotransfer control and luciferase is the reporter gene for lines 1-5.

a CAT activity (percent acetylation).

$\mathrm{b}$ Luciferase (light units/10 sec).

c Neo (cpm).

11.5-kb DNA fragment encoding the Adh1-S gene was capable of efficient expression. Thus, all of the cis-acting DNA sequences required for normal expression in cultured cells are present.

Using transient assays, Adh1-S gene expression in cultured cells showed a dramatic dependence on the presence of introns; replacement of the genomic coding region of Adh1-S by its cDNA equivalent reduced the level of ADH1-S activity 50- to 100-fold. The requirement for introns was not a function of the promoter and transcription initiation site of $A d h 1-S$; rather it appeared to be a function of the structure and/or processing of Adh1-S transcribed sequences. The effect of introns on the expression of maize Adh1 gene is similar to the described dependence of mammalian gene expression on splicing. The levels of rabbit $\beta$-globin (Buchman 1986) and SV40 late region (Gruss et al. 1979; Hamer et al. 1979; Hamer and Leder 1979; Lai and Khoury 1979) mRNAs were adversely affected by the removal of introns. Also, removal of mouse dihydrofolate reductase $(d h f r)$ introns resulted in a 10- to 40-fold reduction in the number of $\mathrm{DHFR}^{+}$colonies when $d \mathrm{hfr}$ genes were transfected into hamster cells (Gasser et al. 1982), suggesting that introns had an effect on the level of $d h f r$ expression. This was more directly investigated by Buchman (1986), who observed a 20 -fold increase in the level of expression of the mouse $d h f r$ gene with the addition of a single heteologous intron from the rabbit $\beta$-globin gene.

In addition, we found that the presence of an intron significantly increased chimeric gene expression in maize cells. Increased expression of the bacterial CAT and Neo coding regions and the firefly luciferase cDNA ranged from 5- to 170-fold depending on the particular promoter, intron, and coding region used. RNA mapping demonstrated that the increased level of CAT expression from a gene containing an intron was the result of an increase in the amount of mature, cytoplasmic CAT mRNA and was not the result of increased translation or increased cytoplasmic stability of the mRNA. Our results do not distinguish, however, whether the increased levels of CAT mRNA result from either increased transcription, increased export of spliced mRNA to the cytoplasm, or improved nuclear stability of the RNA. The latter mechanism is consistent with results from work in mammalian cells that the presence of introns does not affect the rate of transcription (Hamer et al. 1979; Lai and Khoury 1979; Gruss et al. 1979) and that unspliced RNA does not accumulate in the nucleus (Hamer et al. 1979; Buchman 1986).

Experimental evidence suggests that the primary mechanism of stimulation is not intron specific, but depends on splicing per se. In this work, maize ADH1-S activity is stimulated when either the first intron or the last two are present in the gene. CAT and luciferase expression is stimulated by either maize $A d h 1$ intron 1 or the $B z 1$ intron. These results are consistent with the results from previous investigations. Rabbit $\beta$-globin expression is dramatically increased by inclusion of either of the two introns present in the gene, and $\beta$-globin introns from other species will substitute in enhancing the level of rabbit $\beta$-globin expression (Buchman 1986). These $\beta$-globin introns from other species, while sharing functional homology, do not share extensive sequence homology (Van Ooyen et al. 1979). In addition, SV40 molecules with a deletion of the late mRNA splice site can be rescued by insertion of a heterologous intron, a mouse $\beta$-globin intron (Gruss and Khoury 1980). Thus, for the Adh1 gene and chimeric gene expression in maize and in the cases investigated in mammalian cells, it appears that it is splicing per se rather than specific sequences within an intron that result in higher levels of gene expression in those genes requiring introns for full expression.

The stimulation of expression by introns was position dependent, although the magnitude of this effect depended on the coding region tested. CAT expression was 100-fold higher when the Adh1 intron 1 was positioned between the promoter and the CAT coding region than when $A d h 1$ introns 8 and 9 were located downstream of the CAT coding region. In contrast, expression of the 
Adh1 coding region was only two- to fourfold higher when the Adh1 intron 1 (located 133 nucleotides from the RNA 5' end) was present than when $A d h 1$ introns 8 and 9 (located 952 and 1114 nucleotides from the RNA 5 ' end) were present. A position dependence on the efficiency of intron splicing in animal and yeast cells has been previously observed (Greenspan and Weissman 1985; Klinz and Gallwitz 1985). The yeast actin intron was inserted into four sites of the yeast ras-like YP2 gene, which is normally not spliced, and the splicing of the resulting set of four YP2-actin-intron RNAs was examined in yeast. It was observed that the efficiency of splicing decreased as the intron was located further from the RNA 5' end (Klinz and Gallwitz 1985). Similarly, intron 1 from the human $\beta$-globin gene was spliced more efficiently when located upstream of the HSV tk gene (which normally does not contain any introns) than when located downstream (Greenspan and Weissman 1985). In contrast to our results with chimeric CAT genes, little quantitative effect of the intron position on the total amount of cytoplasmic RNA was observed in yeast and animal cells, and only the ratio of spliced to unspliced RNA changed. We hypothesize that the dependence of CAT expression on the position of intron 1 results from an improved efficiency of splicing of introns near the 5' end of the RNA transcript and the inability of unspliced mRNAs to accumulate in the cytoplasm. Taken together, the current data suggest that for genes that require introns for efficient expression, it is probably the combination of RNA structure and intron position that is the critical factor affecting mRNA accumulation.

There are, however, other genes that do not contain introns but are capable of producing gene products, sometimes at high levels, in the absence of splicing: histones (Kedes 1979), thymidine kinase (McKnight 1980), and, in plants, a seed storage protein of soybean (Vodkin et al. 1983) and the zein storage proteins of maize endosperm (Pederson et al. 1982). In addition, expression of some intron-containing genes is not affected by the removal of introns. For example, the only previous study of the effect of the removal of introns from a plant gene showed that intronless bean phaseolin genes transferred to tobacco were capable of expressing phaseolin protein in callus tissue (Chee et al. 1986). Thus, there is no absolute requirement for introns in the expression of plant and mammalian genes. The mechanism(s) by which the expression of genes is dependent or independent of splicing is unknown.

The results of this work demonstrate that the presence of introns can have a profound effect on the level of expression of genes in maize cells. The inefficient splicing of $A d h 1$ introns in dicot cells (Keith and Chua 1986; J. Callis, unpubl.) precludes the analysis of genes containing Adh1 introns in transgenic dicot plants. Although we have not tested the effect of introns in other species, we suggest that coding regions expressed in plant and animal cells may also show position-dependent intron effects of various magnitudes. Therefore, part of the process of optimizing the expression of tran- scription units, especially for introduced genes that may lack introns, should include examining the effect of the inclusion of introns and at various positions, particularly at the $5^{\prime}$ end of the transcribed region of interest.

\section{Materials and methods}

Materials and plasmids

Restriction enzymes were purchased from Bethesda Research Labs or New England Biolabs. Nylon membrane (Genatran 45) was purchased from Plasco. The protoplast isolation enzymes used were cellulase (Cellulysin, CalBiochem), hemicellulase (Rhozyme, Genecore), and pectinase (Pectolyase Y23, Seishin Pharmaceutical). Maize (Zea mays L.) Black Mexican Sweet (BMS; ATCC 54022) cells were a gift from P. Okubara (Stauffer Chemical Col. pB428, pJD205, pB24, and pMBzl were gifts of Jeff Bennetzen (Purdue University) and Michael Freeling (University of California, Berkeley), Jeff de Wet (Stanford University), John Hunsperger (University of Minnesota), and Oliver E. Nelson, Jr. (University of Wisconsin, Madison), respectively. pCaMVNos, pCaMVNEO, and pUCPiAN7 (pUC8 with the PiAN7 polylinker) were described previously (Fromm et al. 1986).

\section{Plasmid constructions}

The construction, isolation, and analysis of recombinant plasmids were performed using standard techniques (Maniatis et al. 1982; Crouse et al. 1983).

Adhl genes. For $A d h 1$ nucleotide numbers see Dennis et al. (1984). All Adh1 gene constructions containing the whole Adh1 coding region (Fig. 1A,B) were done using pUCl9 as the plasmid vector.

pAdhCaMVneo42 and 43. The 11.5-kb BamHI fragment from pB428 was ligated into the BglII site of pCaMVNEO. There is a single BglII site $3^{\prime}$ of the nos poly(A) addition site. The two plasmids 42 and 43 represent the two orientations of the Adh1 gene relative to the neo gene.

pAdhgA. The BamHI-Xhol DNA fragment containing the Adh1-S gene was cloned into the BamHI-SalI site of pUC19. This gene contains $1.1 \mathrm{~kb}$ of $5^{\prime}$ nontranslated Adh1 sequences, the full coding region containing all nine of the introns, the $3^{\prime}$ untranslated region, the poly $(\mathrm{A})$ addition sites, and approximately $2.1 \mathrm{~kb}$ of $A d h 13^{\prime}$-flanking sequences. This Adh1-S gene has an EcoRI site $5^{\prime}$ of the BamHI site (from the polylinker of pUC19). This EcoRI site was utilized in the constructions described below.

$p A d h A 8,9$. This plasmid has the same Adh1-S flanking regions as pAdhgA and codes for the same ADH1-S polypeptide, but contains only the last two introns 8 and 9 by replacement of the coding region with equivalent cDNA sequences from pB24.

pAdhA1,8,9. This plasmid is equivalent to pAdhA8,9 described above with the exception that it includes the first intron.

$p A d h c A$. A single nucleotide difference is responsible for the difference in the electrophoretic mobility of the two isozymes, from an A residue at position 3026 in S /see Sachs et al. 1986 for numbering) to a $\mathrm{G}$ residue in $\mathrm{F}$. pB24 was therefore changed to an S cDNA by site-directed mutagenesis as described by Kunkel 
(1985). The 3' region (a HindIII-SalI fragment) of an Adh1-F cDNA gene (J. Callis, unpubl.) was subcloned into pUC119 to generate a single-stranded (ss) template. This plasmid was propagated in strain BW313, a uracil-incorporating strain, as described by Kunkel (1985). The ssDNA template was annealed to a synthetic 27-mer which spanned position 3026 and contained a single nucleotide mismatch, the A residue corresponding to the $\mathrm{S}$ allele. This primer was extended in the presence of Klenow and T4 DNA ligase at $4^{\circ} \mathrm{C}$ overnight. The resulting reaction was transformed into JM101. Isolated DNA from the resulting colonies was sequenced (Biggin et al. 1983) to verify that it contained the mutation. The HindIII-SalI fragment from a plasmid containing the mutation was ligated to SalI-NcoI fragment of pAdh8,9 (containing pUC19 sequences and 5' Adh1 cDNA sequences) and the NcoI-HindIII of pAdh 8,9 (containing the $5^{\prime}$ half of the protein coding region without introns).

pAdhA1. This plasmid is identical to pAdhcA with the addition of the first intron by replacement of the Adh1 5' region of pAdhcA (BamHI-NcoI fragment) with the equivalent from pAdhgA. The fact that this plasmid functioned as well as pAdhgA (see Results) eliminates the possibility that an additional mutation in the Adh1 coding region in the HindIII-SalI fragment occurred during the mutagenesis.

pAdhA1c. There was a possibility that during the construction of pAdhcAS (during the ligation and propagation), a mutation occurred that is responsible for the lack of active $S$ protein from pAdhcAS. Therefore, the first intron was added back to pAdhcA. This was done by ligating a fragment of pAdhgA containing the $5^{\prime}$-flanking region, first exon, and intron of $A d h 1$ to the $3^{\prime}$ fragment of pAdhcA.

$p A d h \times g A, p A d h \times A 1,8,9$, and $p A d h \times 8,9$. These plasmids are identical to pAdhgA, pAdhAl,8,9, and pAdh8,9, respectively, with the exception that the Adh1 $5^{\prime}$ end point is at at nucleotide $-415 \mathrm{~b}$ instead of $-1.1 \mathrm{~kb}$.

$p g A$. This is an Adh1-S genomic coding region that has had its promoter deleted by Bal31 digestion. This plasmid has a $5^{\prime}$ deletion end point such that it contains 62 nucleotides of the $5^{\prime}$ nontranslated leader (total length 108 nucleotides). The deletion end point was determined by dideoxy nucleotide sequencing (Biggin et al. 1983).

p35SAgA. The construction of a 35S promoter fragment from CaMV has been described (Fromm et al. 1985). It has a BglII site at its $3^{\prime}$ end. The plasmid containing this promoter was restricted with BglII and the cohesive ends were filled in with Klenow and religated. This creates a ClaI site. Plasmids that linearized with ClaI were ligated to ClaI-digested pAdhgA. This construct retains 42 nucleotides of the 103-bp 5' Adh1 leader. p35SgA has the same sequence as pAdhgA downstream of the promoter junction.

p35SA8,9 and p35SA1,8,9. These plasmids are identical to p35SgA in the $5^{\prime}$ - and 3 '-flanking regions, but all of introns except 8 and 9 and all but 1, 8, and 9, respectively, have been removed using cDNA sequences as described above for pAdhA 8,9 and pAdhAl, 8,9.

p35ScA. This plasmid is the $35 \mathrm{~S}$ promoter analog of pAdhcA.

p35SA1. This plasmid is the 35 s promoter analog of pAdhAl.

$p A I_{8,9} A$. The $11.5-\mathrm{kb}$ BamHI fragment from $\mathrm{pB} 428$ containing the entire $A d h 1$ gene was inserted into pUCFiAN/ resticted with BamHI and BglII. Within the Adh1-transcribed region, n!cleotides 73-2551 have been deleted and a BglII linker inserted to facilitate the insertion of the CAT coding region. This yields $\mathrm{pAI}_{8,9} \mathrm{~A}$, which has the Adh1 mRNA 5' start site 81 nucleotides upstream of the $B g I I I$ linker, while the 7.9 -kb downstream fragment contains introns 8 and 9, the 3 ' polyadenylation sites, and flanking region.

$p A C I_{8.9} A$ and $p A C I_{1.9} A$. The BamHI-BglII 790-bp CAT fragment from pUC $\pi$ CAT (Callis et al. 1987) was inserted into the BglII site of $\mathrm{pAI}_{8,9} \mathrm{~A}$. The 10.3-kb BclI-BamHI Adh1 fragment containing all nine introns was substituted for the $3^{\prime}$ region of $\mathrm{pACI}_{8,9} \mathrm{~A}$ to yield $\mathrm{pACI}_{1-9} \mathrm{~A}$.

$p A I_{1} \mathrm{CI}_{8,9} A$ and $p A C I_{1,8,9} A$. A CAT plasmid with a $B g l$ II site at the $5^{\prime}$ end of the CAT gene and a BamHI site at the $3^{\prime}$ end of the CAT gene was inserted into $\mathrm{pAI}_{8,9} \mathrm{~A}$ in order to have a $B g I I I$ site between the Adhl promoter and the CAT gene (pBglII-5'$\left.\mathrm{ACI}_{8,9} \mathrm{~A}\right)$. A 557-bp $A d h 1$ intron 1 fragment spanning nucleotides 119 (BclI) to 672 (trimmed with Bal31 nuclease to remove a flanking ATG sequence, adapted to a $B a m H I$ site, and verified by sequencing) was inserted into pBglII- $5^{\prime}-\mathrm{ACI}_{8,9} \mathrm{~A}$ to yield $\mathrm{pAI}_{1} \mathrm{CI}_{8,9} \mathrm{~A}$. The $557 \mathrm{BclI}-\mathrm{BamHI} A d h 1$ intron 1 fragment was inserted into the BglII site at the $3^{\prime}$ end of the CAT coding region in $\mathrm{pACI}_{8,9} \mathrm{~A}$ to yield $\mathrm{pACI} \mathrm{A}_{1,8,9} \mathrm{~A}$.

pACN and $p A I_{1} C N$. The BamHI-HindIII 277-bp Nos ' polyadenylation region from $\mathrm{pCaMVNEO}$ was substituted for the $3^{\prime}$ end of $A d h 1$ in $\mathrm{pACI}_{8,9} \mathrm{~A}$ to yield pACN. $\mathrm{pAI}_{1} \mathrm{CN}$ was derived from $\mathrm{pAI}_{1} \mathrm{CI}_{8,9} \mathrm{~A}$ by exchanging the $A d h 13^{\prime}$ end for that of the 277-bp BamHI-HindIII bounded Nos 3' polyadenylation region.

$p A_{X} C N, p I_{1} A_{X} C N, p I_{1, i n v} A_{X} C N, p A_{X} C N I_{1}, p A_{X} C N I_{1, \text { inv }}$, and $p A_{X} I_{1} C N$. A $1.5-\mathrm{kb} X b a \mathrm{I}$ fragment containing the 486-bp $A d h 1$ promoter, CAT gene, and Nos polyadenylation region was inserted into the $X b a$ I site of pUCPiAN7 in both orientations to yield $\mathrm{pA}_{\mathrm{x}} \mathrm{CN}-\mathrm{a}$ and $\mathrm{pA}_{\mathrm{X}} \mathrm{CN}-\mathrm{b}$. The $557 \mathrm{BcII}-\mathrm{BamHI}$ $A d h 1$ intron 1 fragment was inserted into the $B a m H I$ site of both $\mathrm{pA}_{\mathrm{x}} \mathrm{CN}-\mathrm{a}$ and $\mathrm{pA}_{\mathrm{x}} \mathrm{CN}$-b in both orientations to yield the set of four $\mathrm{pA}_{X} \mathrm{CN}-\mathrm{I}_{1}$ plasmids shown in Figure 1 (lines 9-12). $\mathrm{pA}_{\mathrm{X}} \mathrm{I}_{1} \mathrm{CN}$ was derived from $\mathrm{pAI}_{1} \mathrm{CN}$ as an $\mathrm{XbaI}$ fragment and inserted into pUCPiAN7.

pCaMVCN and CaMVI ${ }_{1} C N$. pCaMVCN was derived from pCAMVNEO by replacement of the Neo region with that of the CAT coding region. The addition of the BclI-BamHI Adh1 intron 1 fragment to the $B a m H I$ site at the 5 ' end of the CAT gene yielded pCAMVI $\mathrm{CN}$.

$p N C N$ and $p N I_{1} C N$. The 1350-bp EcoRI-BamHI Nos promoter fragment from pNOSCAT was inserted upstream of the CAT coding region attached to the 277 -bp Nos $3^{\prime}$ polyadenylation region to form pNCN. The 557-bp Bcll to BamHI Adhl intron 1 fragment was inserted into the BamHI site at the 5' end of the CAT coding region of $\mathrm{pNCN}$ to form $\mathrm{pNI}_{1} \mathrm{CN}$.

$p A c d n a C N$ and pAcdna $a_{i n v} C N$. A 23-bp double-stranded synthetic oligonucleotide with a sequence identical to the exon portions of the $A d h 1$ intron 1 fragment was inserted in both orientations into the pBglII-5'- $\mathrm{pACI}_{8,9} \mathrm{~A}$ construct described above, and the $A d h 1$ promoter-cDNA-CAT region of each was moved into pACN as an EcoRI fragment to yield pAcdnaCN and pAcdna ${ }_{\text {inv }} \mathrm{CN}$.

$p C a M V B z C N$ and $p C a M V B z_{i n v} C N$. The 156-bp HpaII frag- 
ment of the $B z 1$ gene of maize (Fedoroff et al. 1984) was cloned into the $A c c$ I site of pUCPiAN7 such that it could be excised as a BamHI-BglII fragment. Insertion of the BamHI-BglII $B z 1$ intron fragment in both orientations into the BamHI site of pCaMVCN yielded the desired constructs.

$p C a M V L N, p C a M V B z L N$ and $p C a M V B z_{i n v} L N$. Insertion of the 1.8-kb 5' BamHI-3' BglII luciferase cDNA coding region (de Wet et al. 1987) into pCaMVNOS yielded pCaMVLN. Insertion of the BamHI-BglII Bzl intron fragment into the $5^{\prime}$ BamHI site of pCaMVLN yielded pCaMVBzLN and $p C a M V B z_{i n v} L N$.

pCaMVI ${ }_{1} L N$ and $p C a M V I_{1} n e o N$. The 557-bp BclI-BamHI $A d h 1$ intron 1 fragment was inserted into pCaMVNOS to yield pCaMVI ${ }_{1} \mathrm{~N}$. Insertion of either the $1.8-\mathrm{kb}$ luciferase $15^{\prime}$ BamHI-3' BgIII) or the 1.0-kb BamHI Neo fragments yielded pCaMVI ${ }_{1} \mathrm{LN}$ and $\mathrm{pCaMVI}_{1}$ neoN, respectively.

$p A L N$ and $p A I_{1} L N$. The 1.8 -kb firefly luciferase coding region fragment $\left(5^{\prime}\right.$ BglII- 3' BamHI) was inserted into $\mathrm{pAI}_{1} \mathrm{~N}$ to yield pAI ${ }_{1} \mathrm{LN}$. pAI ${ }_{1} \mathrm{~N}$ contains the $A d h 1$ promoter, $A d h 1$ intron 1 fragment, and the Nos 3 ' polyadenylation region. pALN was constructed by replacing the CaMV 35 S promoter of $\mathrm{pCaMVLN}$ with that of the Adh1 promoter fragment of $\mathrm{pAI}_{8,9} \mathrm{~A}$.

\section{Stable transformations}

Maize calli expressing ADHl-S activity were produced essentially according to Fromm et al. (1986) by electroporation-mediated gene transfer into protoplasts and the subsequent growth of these protoplasts into calli. A total of $50 \mu \mathrm{g}$ of DNA was used per sample. Transformation with pCaMVNEO served as a positive control.

\section{Genomic DNA isolation and Southern analysis}

Genomic DNA from transformed calli was isolated as described in Chilton et al. (1982). DNA was digested with XbaI and BglII, according to the supplier's instructions, electrophoresed, and transferred to Genatran as described by Chandler and Walbot (1986). pB428 was digested with BglII, electrophoresed in a $1 \%$ low-melting agarose gel (Seaplaque, Marine Colloids), and the 888 -bp fragment was isolated and labeled with ${ }^{32} \mathrm{P}$ by hexamer labeling (Feinberg and Vogelstein 1983). Hybridization and wash conditions were as described by Chandler and Walbot (1986).

\section{Transient assays}

Transient expression was measured $36-48 \mathrm{hr}$ after electroporating BMS protoplasts (Fromm et al. 1985, 1987) in the presence of $20 \mu \mathrm{g} / \mathrm{ml}$ of each chimeric plasmid DNA or $50 \mu \mathrm{g} / \mathrm{ml} \mathrm{Adh1}$ plasmid DNA and $10-20 \mu \mathrm{g} / \mathrm{ml}$ of the cotransfer control plasmid DNA. Because levels of gene expression vary between separate isolates of protoplasts, each set of comparisons of gene expression was performed on aliquots of a different, single batch of protoplasts. The level of expression of the cotransfer control plasmid in different electroporated samples varied less than threefold in a batch of protoplasts. The corrected ratios of expression levels from different gene structures varied by less than threefold between protoplast batches.

\section{Enzyme activity assays}

$A D H$ assays. Calli were ground in $15 \%$ glycerol/10 mM
$\mathrm{NaPO}_{4} / 3 \mathrm{~mm}$ DTT ( $\left.\mathrm{pH} 8\right)(\mathrm{EB})$ and spun for $5 \mathrm{~min}$ at $2000 \mathrm{~g}$. The protein content of the supernatants was determined according to Lowry et al. (1951). Aliquots of extracts containing equal amounts of protein were electrophoresed at $4^{\circ} \mathrm{C}$ in $7 \%$ polyacrylamide gels as described by Laemmli (1970), except that the SDS was omitted and $15 \%$ glycerol added. The gels were stained in situ for ADH as described by Schwartz and Endo (1966). The relative amount of ADHI-S activity from the different $A d h 1$ constructs in transient assays was quantitated after drying the gel and scanning the gel with a densitometer. The values for the ADHI-S band were normalized both to total protein and to the ADH $-\mathrm{F}$ homodimer band. There is a range of $\mathrm{ADH}$ activity where there is a linear relationship between the amount of $\mathrm{ADH}$ activity and the staining intensity (data not shown). Therefore, when quantitating the difference between the ADH1-S activity produced by different gene constructs, care was taken to ensure that the measured activity was in the linear range of the assay.

CAT assays. Extracts were prepared and assayed for CAT activity as described (Gorman et al. 1982; Fromm et al. 1985) except that the heat step was at $60^{\circ} \mathrm{C}$ for $10 \mathrm{~min}$. All $\left[{ }^{14} \mathrm{C}\right] \mathrm{chlor}-$ amphenicol containing spots on the TLC silica gel were cut out and counted to determine the percentage of acetylated chloramphenicol.

Luciferase assays. Protoplasts were collected and centrifuged at $200 \mathrm{~g}$ for $5 \mathrm{~min}$. The protoplast pellet was resuspended in 400 $\mu \mathrm{l}$ of $100 \mathrm{~mm}$ potassium phosphate buffer $(\mathrm{pH} 7.8), 1 \mathrm{~mm}$ DTT and sonicated for $10 \mathrm{sec}$. Cell debris was removed by centrifugation and $50 \mu \mathrm{l}$ of the supernatant was added to $200 \mu \mathrm{l}$ assay buffer $\left(25 \mathrm{mM}\right.$ Tricine, $15 \mathrm{mM} \mathrm{MgCl}_{2}, 5 \mathrm{~mm} \mathrm{ATP}$, and 500 $\mu \mathrm{g} / \mathrm{ml}$ bovine serum albumin) in an assay tube. The tube was placed in a luminometer (Analytical Luminescence Laboratories, model 2001) and the reaction was started by injecting 100 $\mu \mathrm{l}$ of $0.5 \mathrm{~mm}$ luciferin (Analytical Luminescence Laboratories). The number of light units per $10 \mathrm{sec}$ was recorded.

Neomycin phosphotransferase II assay. The protocol of Reiss et al. (1983) was used except that the extraction buffer did not contain SDS. The radioactive bands were visualized by autoradiography, excised, and counted.

\section{RNA isolation and mapping}

RNA was isolated from protoplasts $24 \mathrm{hr}$ after electroporation with either pAcdnaCN or $\mathrm{pAI}_{1} \mathrm{CN}$ DNA by the guanidinium isothiocyanate/ $\mathrm{CsCl}$ method (Setzer et al. 1980). The resuspended RNA was treated with RNase-free DNase I, phenol-extracted, and ethanol-precipitated. The transcription and purification of the ${ }^{32} \mathrm{P}$-labeled probe, as well as the hybridization to RNA, subsequent digestion, and gel electrophoresis were performed using published procedures (Melton et al. 1984).

\section{Acknowledgments}

We thank Charles Yanofsky for synthesis of the oligonucleotides. We thank P. Bedinger, P. Leon, C. Gasser, J. de Wet, and P. McLaughlin for helpful discussion. We also thank Sarah Hake and Ray Pacovsky for critically reading the manuscript. This work was supported by a research grant GM 32422 (V.W.) from the National Institutes of Health, a McKnight predoctoral traineeship (J.C.), a Pioneer Hi-Bred International Inc. fellowship (M.F), and the United States Department of Agriculture, Agricultural Research Service (M.F.). 


\section{References}

Beck, E., G. Ludwig, E.A. Auerswald, B. Reiss, and H. Schaller. 1982. Nucleotide sequence and exact location of the neomycin phosphotrasferase gene from transposon Tn5. Gene 19: $327-336$.

Bennetzen, J., J. Swanson, W.C. Taylor, and M. Freeling. 1984. DNA insertion in the first intron of Adh1 affects message levels: Cloning of progenitor and mutant alleles. Proc. Natl. Acad. Sci. 81: 4125-4128.

Bevan, M., W.M. Barnes, and M.-D. Chilton. 1983a. Structure and transcription of the nopaline synthase gene region of T-DNA. Nucleic Acids Res. 11: 369- 385.

Bevan, M.W., R.B. Flavell, and M.-D. Chilton. 1983b. A chimaeric antibiotic resistance gene as a selectable marker for plant cell transformation. Nature 304: 184-187.

Biggin, M.D., T.J. Gibson, and G.F. Hong. 1983. Buffer gradient gels and ${ }^{35}-\mathrm{S}$ label as an aid to rapid DNA sequence determination. Proc. Natl. Acad. Sci. 80: 3963-3965.

Buchman. 1986. "Analysis of mammalian introns and promoters using SV40 recombinant genomes." Ph.D. thesis. Stanford University.

Callis, J., M. Fromm, and V. Walbot. 1987. Expression of mRNA electroporated into plant and animal cells. Nucleic Acids Res. 15: 5823-5831.

Chandler, V.L. and V. Walbot. 1986. DNA modification of a maize transposable element correlates with loss of activity. Proc. Natl. Acad. Sci. 83: 1767- 1771.

Chee, P.P., C. Klassy, and J. Slightom. 1986. Expression of a bean storage protein "phaseolin minigene" in foreign plant tissues. Gene 41: 47- 57.

Chilton, M.D., D. Tepfer, A. Petit, C. David, F. Casse-Delbart, and J. Tempe. 1982. Agrobacterium rhizogenes inserts T-DNA into genomes of the host plant root cells. Nature 295: $432-434$.

Crouse, G.F., A. Frischauf, and H. Lehrach. 1983. An integrated and simplified approach to cloning into plasmids and singlestranded phages. Methods Enzymol. 101: 78-89.

Darnell, J.E. 1978. Implications of RNA-RNA splicing in evolution of eukaryotic cells. Science 202: 1257-1260.

Dennis, E.S., W.L. Gerlach, A.J. Pryor, J.L. Bennetzen, A. Inglis, D. Llewellyn, M.M. Sachs, R.J. Ferl, and W.J. Peacock. 1984. Molecular analysis of the alcohol dehydrogenase (Adh1) gene of maize. Nucleic Acids Res. 12: 3983-4000.

DePicker, A., S. Stachel, P. Dhaese, P. Zambryski, and H.M. Goodman. 1982. Nopaline synthase: Transcript mapping and DNA sequence. J. Mol. Appl. Genet. 1: 561-573.

de Wet, J.R., J.V. Wood, M. DeLuca, D.R. Helinski, and S. Subramani. 1987. The firefly luciferase gene: Structure and expression in mammalian cells. Mol. Cell. Biol. 7: 725-737.

Doolittle, W.F. 1978. Genes in pieces: Were they ever together? Nature 272: 581-582.

Dooner, H.K. and O.E. Nelson, Jr. 1977. Genetic control of UDP-glucose: Flavonol 3-0-glucosyltransferase in the endosperm of maize. Biochem. Genet. 15: 509-519.

Ellis, J.G., D.J. Llewellyn, E.S. Dennis, and W.J. Peacock. 1987. Maize Adh1 promoter sequences control anaerobic regulation: Addition of upstream promoter elements from constitutive genes is necessary for expression in tobacco. EMBO $I$. 6: $11-16$.

Fedoroff, N.V., D.B. Furtek, and O.E. Nelson, Jr. 1984. Cloning of the bronze locus in maize by a simple and generalizable procedure using the transposable controlling element Activator (Ac). Proc. Natl. Acad. Sci. 81: 3825-3829.

Feinberg, A.P. and B. Vogelstein. 1983. A technique for radiolabeling DNA restriction endonuclease fragments to high specific activity. Anal. Biochem. 132: 6-13.
Fraley, R.T., S.G. Rogers, R.B. Horsch, P.R. Sanders, J.S. Flick, S.P. Adams, M.L. Bittner, L.A. Brand, C.L. Fink, J.S. Fry, G.R. Galluppi, S.B. Goldberg, N.L. Hoffman, and S.C. Woo. 1983. Expression of bacterial genes in plant cells. Proc. Natl. Acad. Sci. 80: 4803-4807.

Freeling, M. 1974. Dimerization of multiple maize ADHs: Studies in vivo and in vitro. Biochem. Genet. 12: 407-417.

Freeling, M. and D.C. Bennett. 1985. Maize Adh1. Annu. Rev. Genet. 19: 297-323.

Fromm, M. and Berg, P. 1983. Simian virus 40 early and late region promoter functions are enhanced by the 72 basepair repeat inserted at distant locations and inverted orientations. J. Mol. Appl. Genet. 2: 127-135.

Fromm, M., J. Callis, L.P. Taylor, and V. Walbot. 1987. Electroporation of DNA and RNA into plant protoplasts. Methods Enzymol. 153: (in press).

Fromm, M., L.P. Taylor, and V. Walbot. 1985. Expression of genes transferred into monocot and dicot plant cells by electroporation. Proc. Natl. Acad. Sci. 82: 5824-5828.

. 1986. Stable transformation of maize after gene transfer by electroporation. Nature 319: 791-793.

Furtek, D. 1986. "Cloning and sequence analysis of the Bronze locus of maize: Location of transposable element insertions and comparison of two wild-type alleles." Ph.D. thesis. University of Wisconsin.

Gasser, C.S., C.C. Simonsen, J.W. Schilling, and R.T. Schimke. 1982. Expression of abbreviated mouse dihydrofolate reductase genes in cultured hamster cells. Proc. Natl. Acad. Sci. 79: $6522-6526$.

Gilbert, W. 1978. Why genes in pieces? Nature 271: 501.

Gorman, C.M., L.F. Moffat, and B.H. Howard. 1982 Recombinant genomes which express chloramphenicol acetyltransferase in mammalian cells. Mol. Cell. Biol. 2: 1044-1051.

Greenspan, D.S. and S.M. Weissman. 1985. Synthesis of predominantly unspliced cytoplasmic RNAs by chimeric herpes simplex virus type 1 thymidine kinase-human betaglobin genes. Mol. Cell. Biol. 5: 1894-1900.

Gruss, P., C.J. Lai, R. Dhar, and G. Khoury. 1979. Splicing as a requirement for biogenesis of functional 16S mRNA of simian virus 40. Proc. Natl. Acad. Sci. 76: 4317-4321.

Gruss, P. and G. Khoury. 1980. Rescue of splicing defective mutant by insertion of an heterologous intron. Nature 286: $634-637$.

Hamer, D.H. and P. Leder. 1979. Splicing and the formation of stable mRNA. Cell 18: 1299-1302.

Hamer, D.H., K.D. Smith, S.H. Boyer, and P. Leder. 1979. SV40 recombinants carrying rabbit $\beta$-globin coding sequence. Cell 17: $725-735$.

Herrera-Estrella, L., A. DePicker, M. Van Montagu, and J. Schell. 1983. Expression of chimaeric genes transferred into plant cells using a Ti-plasmid- derived vector. Nature 303: 209-213.

Kedes, L.H. 1979. Histone gene and histone messengers. Annu. Rev. Biochem. 48: 837-870.

Keith, B. and N.-H. Chua. 1986. Monocot and dicot pre-mRNAs are processed with different efficiencies in transgenic tobacco. EMBO J. 5: 2419-2425.

Klinz, F.-J. and D. Gallwitz. 1985. Size and position of intervening sequences are critical for the splicing efficiency of pre-mRNA in the yeast Saccharomyces cerevisiae. Nucleic Acids Res. 13: 3791-3804.

Kunkel, T.A. 1985. Rapid and efficient site-directed mutagenesis without phenotypic selection. Proc. Natl. Acad. Sci. 82: $488-492$.

Laemmli, U.K. 1970. Cleavage of structural proteins during the assembly of the head of bacteriophage T4. Nature 227: 680 685. 


\section{Callis et al.}

Lai, C.-J. and G. Khoury. 1979. Deletion mutants of simian virus 40 defective in biosynthesis of late viral mRNA. Proc. Natl. Acad. Sci. 76: 71-75.

Leff, S.E., M.G. Rosenfeld, and R.M. Evans. 1986. Complex transcriptional units: Diversity in gene expression by alternative RNA processing. Annu. Rev. Biochem. 55: 10911117.

Lowry, O.H., N.J. Rosebrough, A.L. Farr, and R.J. Randall. 1951. Protein measurement with the folin reagent. J. Biol. Chem. 139: 265-275.

Maniatis, T. and R. Reed. 1987. The role of small nuclear ribonucleoprotein particles in pre-mRNA splicing. Nature 325: 673-678.

Maniatis, T., E.F. Fritsch, and J. Sambrook. 1982. Molecular cloning: A laboratory manual. Cold Spring Harbor Laboratory, Cold Spring Harbor, New York.

McKnight, S.L. 1980. The nucleotide sequence and transcription map of the herpes simplex virus thymidine kinase gene. Nucleic Acids Res. 8: 5949-5964.

Melton, D.A., P.A. Krief, M.R. Rebagliati, T. Maniatis, K. Zinn, and M.R. Green. 1984. Efficient in vitro synthesis of biologically active RNA and RNA hybridization probes from plasmids containing a bacteriophage SP6 promoter. Nucleic Acids Res 12: 7035-7056.

Padgett, R.A., P.J. Grabowski, M.M. Konorska, S. Seiler, and P. Sharp. 1986. Splicing of messenger RNA precursors. Annu. Rev. Biochem. 55: 1119- 1150 .

Pederson, K., J. Devereux, D. Wilson, E. Sheldon, and B. Larkins. 1982. Cloning and sequence analysis reveal structural variation among related zein genes in maize. Cell 29: 1015-1026.

Ptashne, M. 1986. Gene regulation by proteins acting nearby and at a distance. Nature 322: 697-701.

Reiss, B., R. Sprengel, H. Will, and H. Schaller. 1984. A new sensitive method for qualitative and quantitative assay of neomycin phosphotransferase in crude cell extracts. Gene 30: $211-218$.

Sachs, M.M., E.S. Dennis, W.L. Gerlach, and W.J. Peacock. 1986. Two alleles of maize alcohol dehydrogenase 1 have 3 structural and poly (A) polymorphisms. Genetics 113: 449467.

Schwartz, D. and T. Endo. 1966. Alcohol dehydrogenase polymorphism in maize-simple and compound loci. Genetics 53: 709-715.

Setzer, D.R., M. McGrogan, J.H. Nunberg, and R.T. Schmike. 1980. Size heterogeneity in the $3^{\prime}$ end of dihydrofolate reductase messenger RNAs in mouse cells. Cell 22: 361-370.

Sharp, P. 1987. Splicing of messenger RNA precursors. Science 235: 766-771.

Southern, P.J. and P. Berg. 1982. Transformation of mammalian cells to antibiotic resistance with a bacterial gene under control of the SV40 early region promoter. I. Mol. Appl. Genet. 1: 327-341.

Treisman, R., U. Novak, J. Favaloro, and R. Kamen. 1981. Transformation of rat cells by an altered polyoma virus genome expressing only middle- $\mathrm{T}$ protein. Nature 292: $595-600$.

van Ooyen, A., J. van den Berg, N. Mantei, and C. Weissmann. 1979. Comparison of total sequence of a cloned rabbit $\beta$ globin gene and its flanking regions with a homologous mouse sequence. Science 206: 337-344.

Vodkin, L.O., P.R. Rhodes, and R.B. Goldberg. 1983. A lectin gene insertion has the structural features of a transposable element. Cell 34: 1023-1031.

Woodman, J.C. and M. Freeling. 1981. Identification of a genetic element that controls the organ-specific expression of Adh1 in maize. Genetics 98: 357-378. 


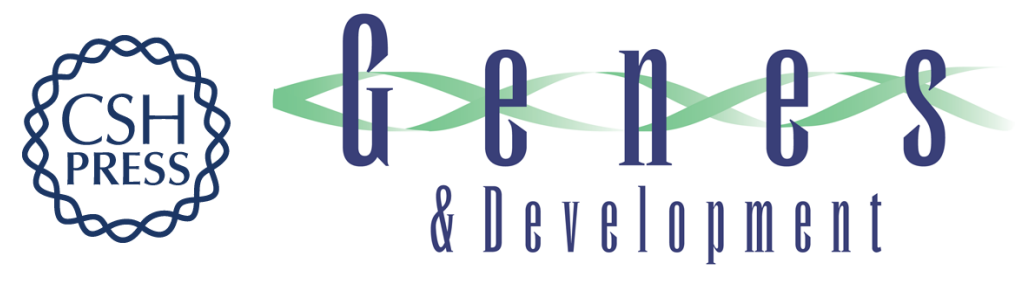

\section{Introns increase gene expression in cultured maize cells.}

$\mathrm{J}$ Callis, M Fromm and V Walbot

Genes Dev. 1987, 1:

Access the most recent version at doi:10.1101/gad.1.10.1183

References This article cites 58 articles, 19 of which can be accessed free at: http://genesdev.cshlp.org/content/1/10/1183.full.html\#ref-list-1

License

Email Alerting Receive free email alerts when new articles cite this article - sign up in the box at the top Service right corner of the article or click here.

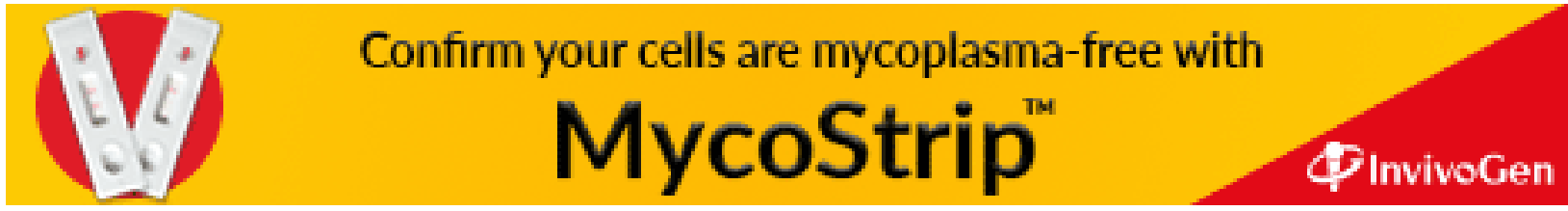

